UNIVERSIDADE DO VALE DO RIO DOS SINOS - UNISINOS

UNIDADE ACADÊMICA DE PÓS-GRADUAÇÃO

ESCOLA DE GESTÃO E NEGÓCIOS

MBA EM NEGÓCIOS E EMPREENDIMENTOS INTERNACIONAIS

BRUNO KOPS ESPANHOL

OS MECANISMOS DE PROTEÇÃO CAMBIAL:

O Caso das Micros e Pequenas Empresas Brasileiras 
BRUNO KOPS ESPANHOL

\section{OS MECANISMOS DE PROTEÇÃO CAMBIAL: \\ O Caso das Micros e Pequenas Empresas Brasileiras}

Projeto Aplicado apresentado como requisito para a obtenção do título de Especialista em Negócios e Empreendimentos Internacionais, pelo MBA em Negócios e Empreendimentos Internacionais da Universidade do Vale do Rio dos Sinos - Unisinos.

Orientador: Prof. Ms. Edmilson Milan 


\section{AGRADECIMENTOS}

Eu sempre tive vontade de nunca parar de estudar e fazer um curso de especialização, mestrado e doutorado, pois acredito que o conhecimento nos leva para próximo de Deus. Por isso, quero agradecer em primeiro lugar a Deus que me permitiu realizar este desejo e me deu tudo que possuo e vou vir a possuir, sendo somente através dele possível adquirir conhecimento.

Agradeço a minha família, minha mãe Elisabete, meu pai Victor e meu irmão caçula Gustavo, pelo amor, carinho e apoio prestados durante o desenvolvimento deste projeto aplicado. Foram eles que me ensinaram a perseverança e a nunca desistir dos meus sonhos, pois tudo é possível alcançar com trabalho duro e esforço.

Ao meu orientador, Prof. Ms. Edmilson Milan, pelas várias contribuições durante todo o processo de desenvolvimento do trabalho, pelo tempo e disponibilidade dedicados, pela indicação dos contatos das empresas e instituições financeiras, pela atenção e as diversas correções efetuadas no decorrer de todo o processo, pelas indicações e sugestões de adições ao trabalho, permitindo que eu pudesse desenvolver este projeto aplicado.

A todos os professores do MBA em Negócios e Empreendimentos Internacionais, pelo conhecimento adquirido durante as aulas, pelas conversas e discussões. Agradeço também a Unisinos que instituiu o curso nesta área de conhecimento que vem crescendo constantemente.

Agradeço a todos os entrevistados, empresários e agentes das instituições financeiras, pela sua disponibilidade e parceria ao responder os questionários semiestruturados e por todas as contribuições e sugestões feitas no decorrer deste trabalho. Este estudo não seria possível sem as suas participações.

Aos meus colegas do MBA, pela amizade, aprendizado e as discussões sobre os temas relevantes na atualidade. Foram os debates constantes e as trocas efetuadas durante as aulas e fora delas que possibilitaram o surgimento deste trabalho.

Obrigado a todos que estiveram comigo nesta caminhada e contribuíram para a realização de mais esta conquista. Desejo o melhor a todos e as bênçãos de Deus. 


\section{RESUMO}

Atualmente o mundo é globalizado e as empresas realizam negócios entre si a partir das mais diversas localidades. Estas operações requerem a importação ou a exportação de produtos e serviços. Entretanto, para adquirir ou vender produtos no exterior, é necessário realizar a contratação de câmbio. A moeda estrangeira é considerada um produto e, portanto, possui um preço: a taxa de câmbio. No entanto, este preço varia constantemente pelos mais diversos fatores. As grandes empresas utilizam mecanismos de proteção cambial, conhecidos como hedge, para evitar variações exacerbadas e a quebra do fluxo de caixa. Entretanto, estes mecanismos são pouco conhecidos pelos micros e pequenos empresários que em sua maioria ficam expostos as variações constantes do câmbio. O presente estudo foi realizado com o objetivo de investigar as opções disponíveis de proteção cambial para os micros e pequenos empreendedores brasileiros. Para isso, foi realizada uma pesquisa qualitativa, de natureza exploratória, na qual foi selecionado três analistas de bancos comerciais e três pequenos empresários que trabalham com comércio exterior, através de amostragem teórica. A técnica de coleta de dados utilizada foi a entrevista com base em um roteiro de questionário semiestruturado, elaborado com base no referencial teórico e nas principais demandas do setor de comércio exterior. A pesquisa demostra que há diversos mecanismos disponíveis para os micros e pequenos empresários nos mercados de derivativos, câmbio e bancário. A partir das entrevistas foi possível identificar um conhecimento limitado dos mecanismos de hedge por parte do micro e pequeno empresário, a percepção das operações de proteção cambial como custo adicional, e uma falta de comunicação efetiva entre bancos e o empresariado deste porte, causado sobretudo pelo desconhecimento do tema. As empresas e instituições financeiras entrevistadas identificam a falta de conhecimento como o principal entrave para a realização da comercialização e utilização deste tipo de operação financeira. Por fim, este estudo apresenta sugestões das operações mais adequadas para os micros e pequenos empresários, além de considerações sobre a divulgação e ensino da importância das operações por parte dos bancos, com o objetivo de aumentar o conhecimento e o uso destes mecanismos neste setor.

Palavras-chave: Proteção cambial. Hedge. Micro e pequenas empresas brasileiras. Comércio exterior. Importação. Exportação. Acesso aos mecanismos de proteção cambial. 


\begin{abstract}
Currently the world is globalized, and companies do business from the most diverse locations. These operations require the import or export of products and services. However, to purchase or sell products abroad it is necessary to contract foreign exchange. Foreign currency is considered a product and therefore has a price: the exchange rate. However, this price varies constantly due to the most diverse factors. Large companies use foreign exchange hedge mechanisms, also known as FOREX hedges, to avoid exacerbated variations and a drop in cash flow. Nevertheless, these mechanisms are little known by micro and small business owners who are the mostly exposed to the constant exchange rate variations. The present study was carried out with the objective of investigating the options available for foreign exchange protection for Brazilian micro and small entrepreneurs. For this, a qualitative research, of an exploratory nature, was carried out, in which three commercial bank analysts and three small businessmen who work with foreign trade were selected, through theoretical sampling. The data collection technique used was the interview based on a semi-structured questionnaire script, prepared based on the theoretical framework and the main demands of the foreign trade sector. The research shows that there are several mechanisms available for micro and small business owners in the derivatives, foreign exchange and banking markets. From the interviews, it was possible to identify a limited knowledge of hedge mechanisms on the part of micro and small entrepreneurs, the perception of foreign exchange protection operations as an additional cost and a lack of effective communication between banks and this sector of the business community, caused mainly by lack of knowledge of the theme. This lack of knowledge was identified by the companies and financial institutions interviewed as the main obstacle to the commercialization and use of this type of financial operation. Finally, this study presents suggestions for the most appropriate operations available to micro and small business owners, in addition to considerations on the marketing and instruction of the importance of these operations to businesses by the banks, with the aim of increasing knowledge and the use of these mechanisms in this sector.
\end{abstract}

Keywords: Currency protection. Hedge. Brazilian micro and small companies. Foreign trade. Import. Export. Access to Exchange protection mechanisms. 


\section{LISTA DE FIGURAS}

Figura 1 - Variação da taxa de câmbio no Brasil .................................................................16

Figura 2 - Volume de negociações dólar futuro ..................................................................19

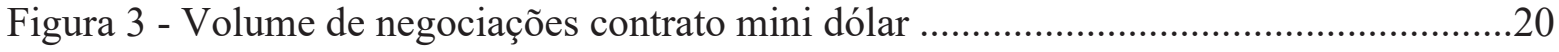

Figura 4 - Volume de negociação opções de compra de dólar ..............................................23

Figura 5 - Volume de negociação de opções de venda de dólar ..........................................24

Figura 6 - Contratos de Swaps DI x Dólar comercial negociados .........................................28

Figura 7 - Volume de negociações Swaps DI x Dólar comercial ............................................29

Figura 8 - Tipo de operação de comércio exterior realizada pelas empresas .......................42

Figura 9 - Autoavaliação dos empresários em relação aos conhecimentos das operações de hedge

Figura 10 - Percepção das instituições financeiras sobre o conhecimento dos empresários das operações de hedge .44

Figura 11 - Acessibilidade à informação sobre operações de hedge segundo os empresários . .45

Figura 12 - Acessibilidade à informação sobre as operações de hedge segundo os bancos ..46 


\section{LISTA DE QUADROS}

Quadro 1 - Classificação de porte dos estabelecimentos segundo a receita bruta......................38 


\section{LISTA DE TABELAS}

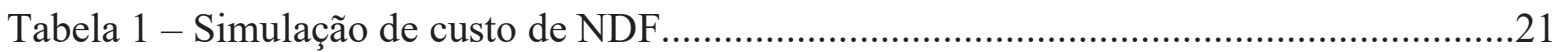

Tabela 2 - Opção de compra de dólar (opção exercida).....................................................26

Tabela 3 - Opção de compra de dólar (opção não exercida).................................................26

Tabela 4 - Simulação de operação de SWAP Dólar comercial X Taxa DI..............................30

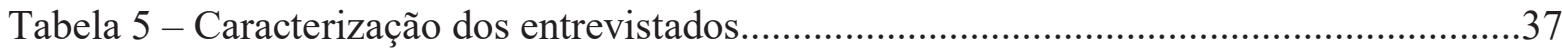

Tabela 6 - Classificação de porte dos estabelecimentos segundo número de empregados.....38

Tabela 7 - As operações de hedge utilizadas pelos empresários e as operações de hedge

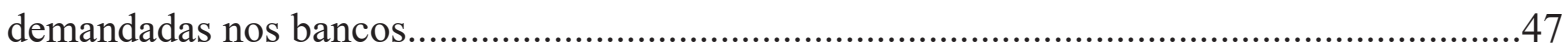

Tabela 8 - Operações de hedge na bolsa de valores: vantagens e desvantagens.....................48

Tabela 9 - As principais dificuldades dos empresários para utilizar operações de hedge.......49 


\section{LISTA DE SIGLAS}

ACC Adiantamento sobre contrato de câmbio

ACE Adiantamento sobre cambiais entregues

BACEN Banco Central do Brasil

CDI Certificado de depósito bancário

DI Depósito bancário

EPP Empresa de pequeno porte

FINIMP Financiamento à importação

IOF Imposto sobre operações financeiras

LIBOR London interbank offered rate

MDIC Ministério da Indústria, Comércio exterior e Serviços

ME Microempresa

MPE Micro e pequenas empresas

NDF Non Deliverable Forward

SEBRAE Serviço Brasileiro de Apoio às Micro e Pequenas Empresas 


\section{SUMÁRIO}

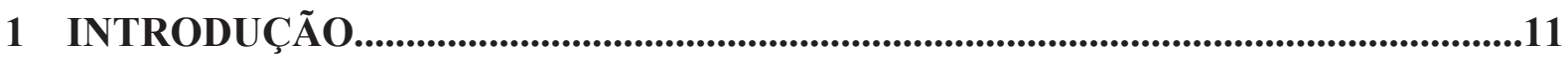

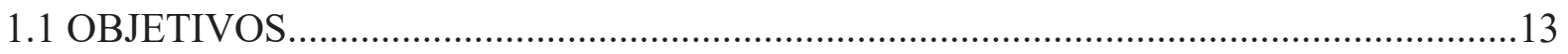

1.1.1 Objetivo geral....................................................................................................................13

1.1.2 Objetivos específicos...........................................................................................13

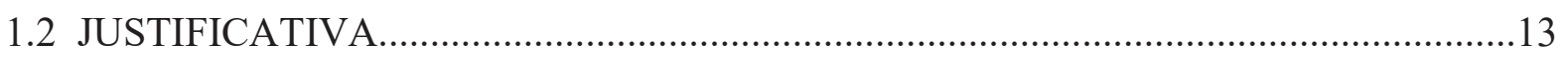

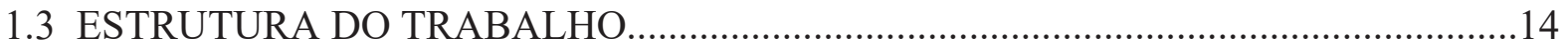

2 REVISÃO DE LITERATURA...................................................................................15

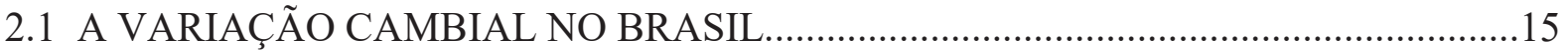

2.2 OS MECANISMOS DE PROTEÇÃO CAMBIAL .......................................................

2.2.1 Principais mecanismos de proteção cambial no mercado de derivativos no

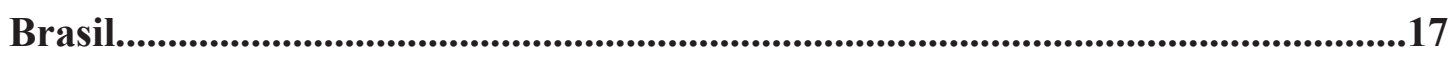

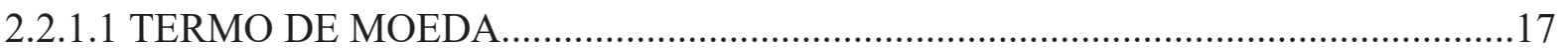

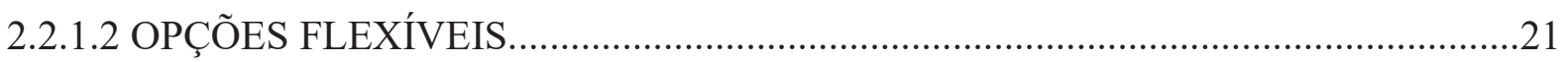

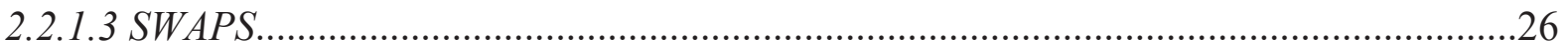

2.2.2 Principais ferramentas de proteção cambial disponíveis no mercado de câmbio

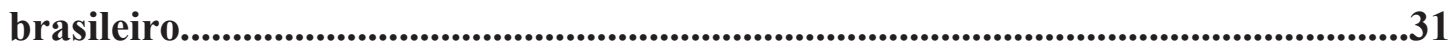

2.2.2.1 PAGAMENTO ANTECIPADO DE IMPORTAÇÃO.................................................

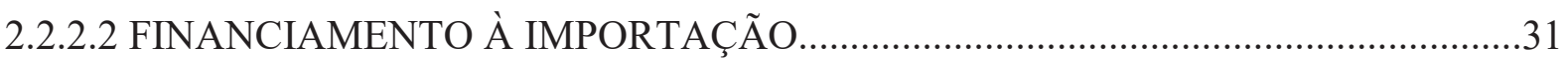

2.2.2.3 CONTRATAÇÃO DE CÂMBIO DE IMPORTAÇÃO COM LIQUIDAÇÃO

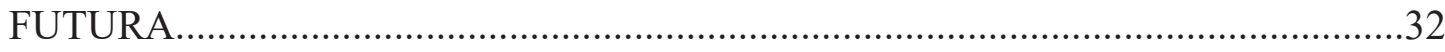

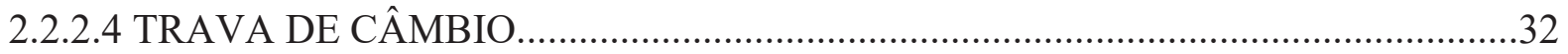

2.2.3 Principais produtos bancários disponíveis...................................................................33

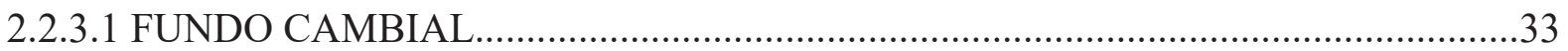

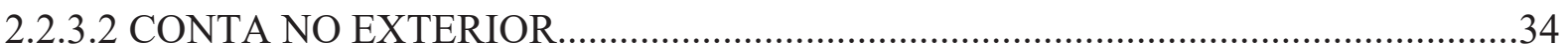

2.2.4 Imposto de renda sobre as operações de proteção cambial.........................................34

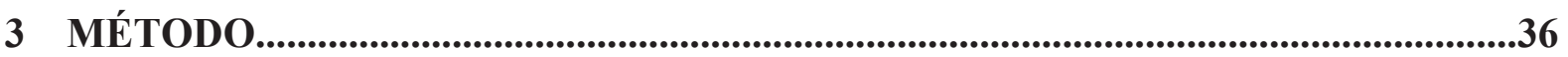

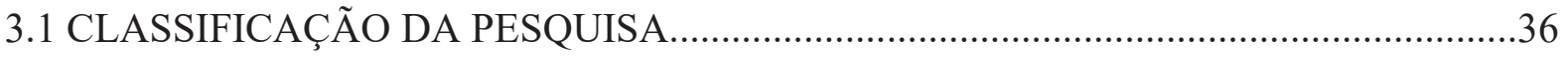

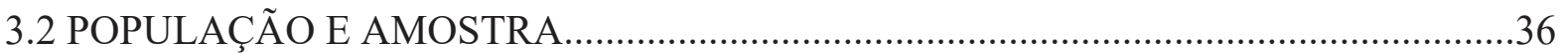

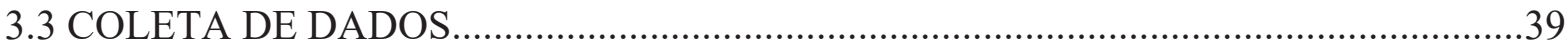

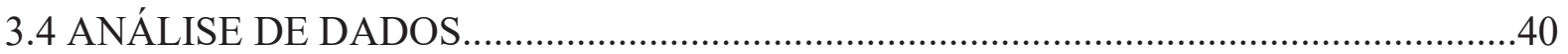

4 RESULTADOS DA PESQUISA.......................................................................................42

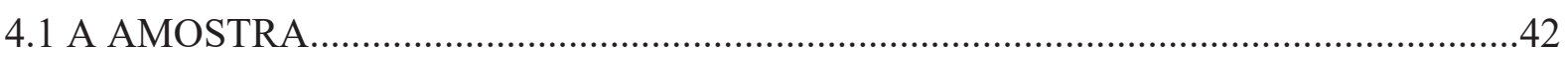


4.2 O CONHECIMENTO DOS AGENTES SOBRE PROTEÇÃO

CAMBIAL

4.3 O ACESSO À INFORMAÇÃO SOBRE AS OPERAÇÕES

DISPONÍVEIS. .44

4.4 AS PRINCIPAIS OPERAÇÕES UTILIZADAS. 46

4.5 AS OPERAÇÕES DE HEDGE (DERIVATIVOS) NA BOLSA DE VALORES 47

4.6 AS DIFICULDADES DOS MICROS E PEQUENOS EMPRESÁRIOS.. .48

5 CONCLUSÃO. .50

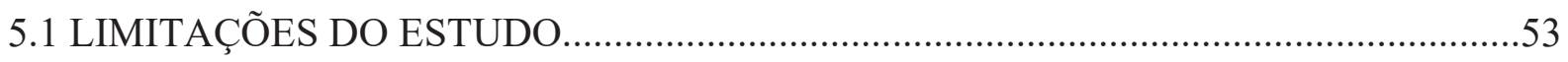

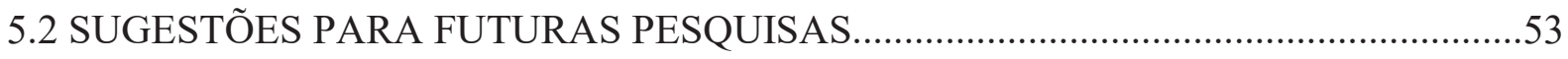

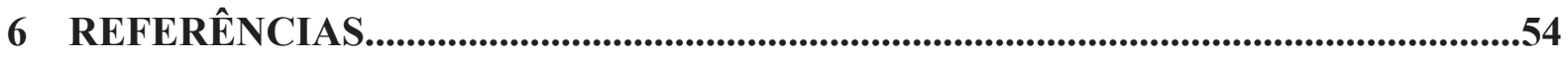

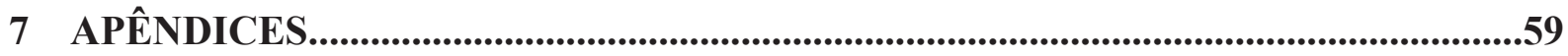

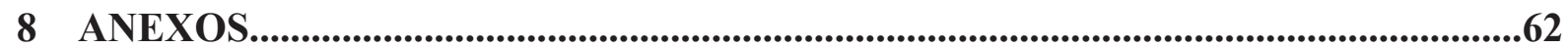




\section{INTRODUÇÃO}

No mundo globalizado de hoje, quando se fala de expansão de empresas, o comércio internacional se torna cada vez mais a regra. O Brasil ainda é um pequeno ator neste cenário em expansão com somente $1,3 \%$ das exportações mundiais e $0,9 \%$ das importações no mundo. Enquanto isso, somente os Estados Unidos representam 9\% das exportações e 13,7\% das importações mundiais. (BANCO MUNDIAL, 2017).

O comércio internacional se caracteriza pela utilização de moedas estrangeiras em suas transações. Neste sentido a variação cambial é um dos principais fatores que afetam o preço final de um produto, tanto na exportação como na importação. (RATTI, 2004).

Grandes empresas utilizam processos de proteção cambial chamados de hedge, geralmente efetuados em dólar e para grandes transações, para mitigar o risco de variação cambial de suas operações. Entretanto, estes processos estão normalmente disponíveis apenas para valores elevados e com custo operacional consideravelmente elevado, inibindo, desta maneira, a participação de micro e pequenas empresas (MPEs) exportadoras e importadoras neste mercado. Estes pequenos empresários ficam totalmente expostos à variação cambial e muitas vezes deixam de vender ou até mesmo vendem com prejuízo quando ocorre uma variação abrupta da moeda nacional. Além disso, o mercado de hedge está limitado no Brasil as seguintes moedas: dólar dos Estados Unidos (dólar), euro e iene japonês (iene). (FIGUEIREDO, 2017) Esta limitação que diminui as possibilidades de proteção cambial e força compradores e vendedores a realizar um duplo câmbio, primeiramente para dólar e após para a moeda do país do qual o bem é importado ou para qual o bem será exportado, elevando consideravelmente o custo da operação e, por consequência, o preço final do produto.

A empresa Espanhol Materiais Fotográficos é um exemplo de microempresa que luta diariamente contra a variação cambial. Especializada na importação e revenda de peças de reposição para Minilabs oriundas dos mais diversos mercados, como China, Japão, Índia, França, entre outros, a empresa está consideravelmente exposta a variações cambiais e participa de um mercado que exige uma qualidade elevada de produto e o menor preço possível. Sem condições de possuir um grande estoque e trabalhando com peças de maior valor agregado sob encomenda, acaba exposta e prejudicada na competição por preço do mercado fotográfico em razão da grande variação do câmbio. Seus principais fornecedores são de países do mercado asiático que operam em moedas distintas e que oferecem uma possibilidade de diminuição de 
preço final do produto por meio da diminuição da exposição cambial e da compra diretamente na moeda local de seus fornecedores.

A empresa enfrenta uma situação provavelmente comum a muitas empresas brasileiras de importação e exportação: a não existência de meios de hedge nas moedas de países asiáticos no mercado brasileiro. Além disso, fica limitada inclusive ao acesso aos derivativos mais simples como Non-Deliverable Forwards (NDF), Opções e Swaps cambiais pelo simples fato de não possuir grande movimentação financeira internacional e falta de acesso aos processos de proteção cambial limitados as grandes empresas.

A economia do mercado asiático cresceu muito nos últimos anos. (BANCO MUNDIAL, 2017). É neste mercado que está localizado o maior parceiro comercial do Brasil: a China, que representa 26,8\% das exportações brasileiras e 19,2\% das importações. Comparativamente, os Estados Unidos da América (EUA) representam 12\% das exportações e 16\% das importações brasileiras. (MINISTÉRIO DA ECONOMIA DO BRASIL, 2019). Entretanto, atualmente as transferências e os procedimentos de proteção cambial nas operações envolvendo a China geralmente são generalizadas em dólar e não na moeda renminbi, que é a moeda chinesa, acarretando custos desnecessários. Por sua vez, o mercado asiático, pelo menos em termos de proteção financeira, torna-se inacessível para muitas empresas. Entretanto, o que ocorreria se fosse possível realizar procedimentos de hedge cambial, nas moedas dos países asiáticos de destino ou origem dos fluxos comerciais? É possível afirmar que a exposição cambial e os custos operacionais envolvidos nas frequentes remessas ao exterior certamente diminuiriam consideravelmente.

É a busca de possíveis resoluções destes dilemas que se trata o problema de pesquisa deste projeto aplicado que pretende diminuir a exposição a variações cambiais de MPEs por meio de mecanismos de hedge, investigando as opções disponíveis para as micro e pequenas empresas (MPEs) brasileiras no mercado financeiro brasileiro. São objetivos deste trabalho aplicado: 


\subsection{OBJETIVOS}

Com o propósito de responder à questão de pesquisa foram estabelecidos os objetivos a seguir relacionados.

\subsubsection{Objetivo geral}

Investigar as opções disponíveis de proteção cambial para as MPEs no mercado financeiro brasileiro.

\subsubsection{Objetivos específicos}

São objetivos específicos deste estudo:

a) Identificar se as empresas têm conhecimento sobre os mecanismos disponíveis e as vantagens de efetuar proteção cambial em suas operações.

b) Conhecer se há acesso às informações às MPEs pertinentes para a realização destas operações.

c) Verificar se é viável realizar proteção cambial com custo reduzido e envolvendo pequenos valores.

\subsection{JUSTIFICATIVA}

O mundo é cada vez mais interdependente. Em nível comercial, o fluxo de mercadorias entre fronteiras cresce constantemente. Neste contexto, o câmbio tornasse relevante, pois para adquirir ou vender mercadorias no exterior, é necessário efetuar a contratação de câmbio no mercado financeiro. (MDIC, 2017). No comércio internacional, o câmbio e sua variação são um dos principais fatores que influencia a negociação e a formação de custo final dos produtos comercializados. As variações cambiais podem ser benéficas ou maléficas para as empresas, podendo levar a grande lucro operacional ou até a beira da falência, como foi o caso em 2008 da Sadia. (GIRARDI, 2016).

As MPEs representavam cerca de 50\% do total de empresas exportadoras do Brasil em 2016. (MDIC, 2017). Estas empresas têm, geralmente, fluxo de caixa reduzido e, por consequência, menor resistência a variação cambial. (SANTOS, 2010). O mercado financeiro possibilita a proteção da variação cambial através de mecanismos de hedge, entretanto, em geral, somente as médias e grandes empresas conseguem acessar estas operações. Este trabalho foi inspirado 
na necessidade de melhor administrar o fluxo de caixa limitado das MPEs por meio da diminuição da sua exposição cambial e da possibilidade de acessar estes procedimentos.

\subsection{ESTRUTURA DO TRABALHO}

Este trabalho aplicado está estruturado em 5 capítulos contando com esta introdução que é o primeiro capítulo. No segundo capítulo, é apresentada a revisão de literatura que serviu de base para a realização deste projeto. No terceiro, é abordada a metodologia que foi utilizada neste trabalho. No quarto, são analisados os resultados buscando responder aos objetivos deste projeto aplicado. E, por fim o capítulo cinco discorre sobre as considerações finais.

A resolução dos dilemas anteriormente citados envolveu principalmente as áreas financeira e de comércio exterior. O foco foi o fator custo e a sua diminuição sem a perda de qualidade do produto, ou seja, a busca de ganho financeiro através da não exposição cambial e a compra diretamente nas moedas dos fornecedores. 


\section{REVISÃO DE LITERATURA}

Este capítulo tem como objetivo expor as diversas opções de proteção cambial disponíveis no mercado financeiro brasileiro. Primeiramente, é apresentado um breve histórico da variação cambial brasileira. Em segundo lugar, são analisados os mecanismos cambiais disponíveis no mercado de derivativos brasileiro. Em terceiro lugar, são analisadas as opções de proteção cambial disponíveis para as empresas por meio do mercado de câmbio. Em quarto lugar, são expostos os produtos bancários disponíveis e a possibilidade de manter recursos no exterior para utilização futura.

\subsection{A VARIAÇÃO CAMBIAL NO BRASIL}

O Brasil possui um histórico de oscilação cambial ao longo de sua história recente. (BACEN, 2020). Com o advento do plano real, as taxas de inflação têm se mostrado em níveis mais estáveis. Todavia, mesmo depois da aprovação deste plano em 1993 e a entrada em circulação da nova moeda em 1994 as oscilações cambiais brasileiras permaneceram relativamente elevadas. (BANCO MUNDIAL, 2020).

Segundo Carneiro, o comércio exterior é fortemente dependente da variação cambial e da previsibilidade a médio e longo prazo da cotação da moeda nacional, no caso do Brasil, o real brasileiro. Entretanto, a economia brasileira tem historicamente se mostrado instável e imprevisível. Esta instabilidade impacta diretamente o comércio internacional e é uma das principais razões pelas quais não possuímos maior participação no comércio mundial. (CARNEIRO, 2014).

A figura 1 demostra que, considerando a média anual da taxa de câmbio, desde o advento do real a taxa de câmbio do real brasileiro frente ao dólar variou de $\mathrm{R} \$ 0,85$ até $\mathrm{R} \$ 3,95$ entre 1994 a 2019, considerando a taxa de câmbio de fechamento do último dia útil do ano. Entretanto diversas variações bruscas de valorização e desvalorização, em especial durante períodos eleitorais, deterioram a estabilidade da moeda e a sua previsibilidade. 
Figura 1 - Variação da taxa de câmbio no Brasil.

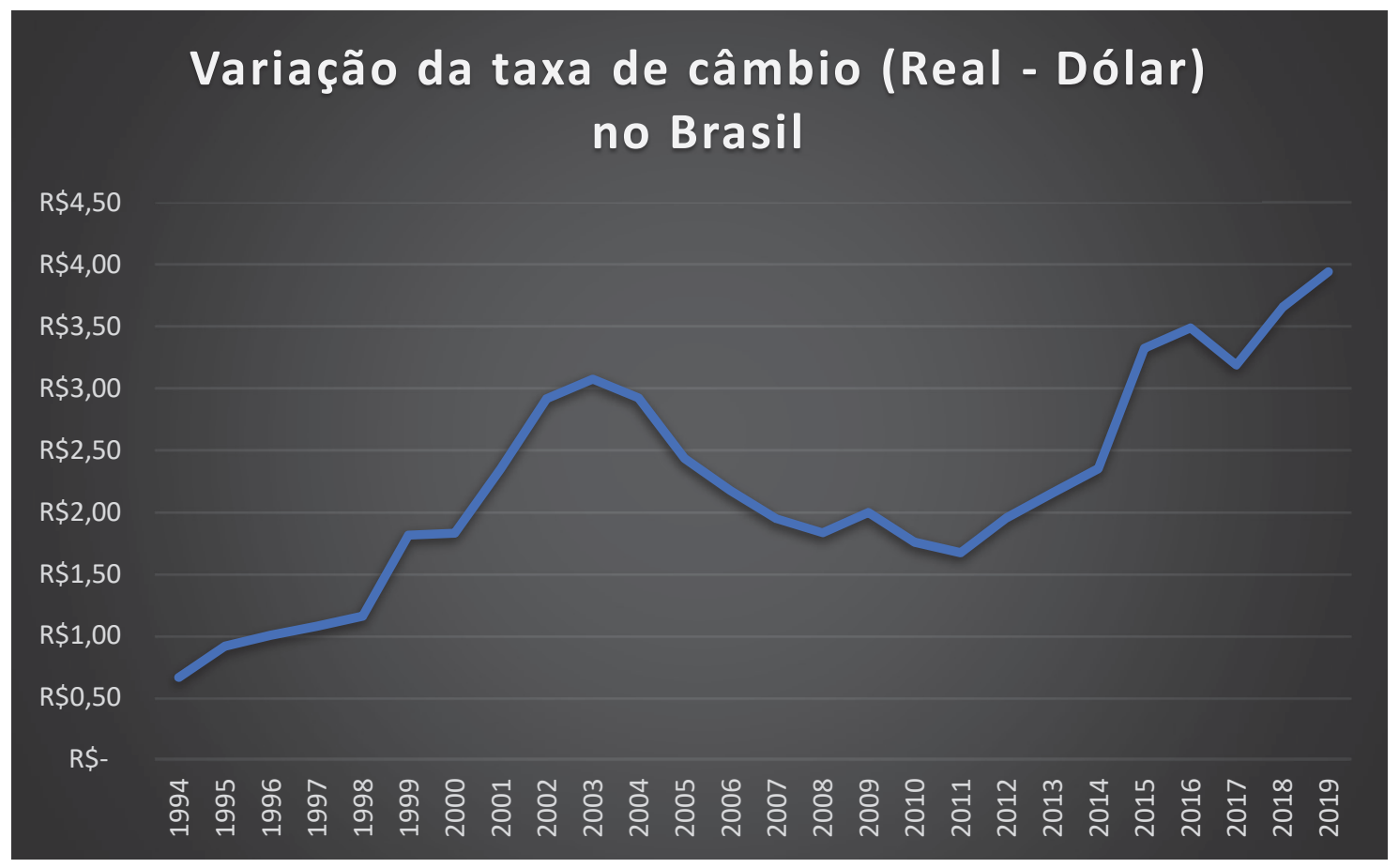

Fonte: Banco Central do Brasil, 2019.

O câmbio é o preço de troca da moeda nacional face a uma moeda estrangeira. Existem diversas razões pelas quais o câmbio varia, sendo as mais conhecidas a oferta e a demanda pela moeda estrangeira, a variação da balança comercial, o nível da taxa de juros nacional, a situação das contas do governo e o risco do Brasil em comparação aos outros países do sistema internacional. Um dos pontos que tendem a apreciar o real frente ao dólar é um superávit comercial, pois se a quantidade de exportações é maior que as importações estão entrando mais dólares no Brasil do que saindo e logo há uma maior demanda por real do que por dólar no âmbito nacional. (ROSSI, 2016).

\subsection{OS MECANISMOS DE PROTEÇÃO CAMBIAL}

A proteção cambial é o ato de evitar as variações da moeda nacional frente a moedas estrangeiras utilizando-se de mecanismos disponíveis no sistema financeiro. Pode ser efetuada por meio dos mercados de derivativos, câmbio e bancário. (HULL, 2016).

No Brasil há curso forçado da moeda, ou seja, a necessidade da compra e venda de moedas através de instituição financeira, desta forma um importador ou exportador deve se dirigir ao mercado de câmbio para efetuar ou receber o pagamento de suas transações. Este procedimento deve ser realizado mesmo quando são utilizados mecanismos de hedge. (RATTI, 2004). 
Neste capítulo será analisada a utilização dos principais produtos do mercado de derivativos, câmbio e bancários. Primeiramente, serão analisados os principais mecanismos de proteção cambial no mercado de derivativos. Em segundo lugar, serão expostos os mecanismos disponíveis no mercado de câmbio. Em terceiro lugar, será exposta uma opção direta no mercado bancário. Por último, será exposto os impostos que incidem sobre estas operações no mercado brasileiro.

As operações do mercado de derivativos podem ser realizadas na bolsa de valores ou através de instituições financeiras autorizadas, como os bancos. Para operação na Bovespa, bolsa brasileira localizada em São Paulo e que atualmente chama-se B3, é necessário a contratação de uma corretora de valores autorizada pelo Bacen, e as operações são estruturadas em lotes padrões e com prazos fixos. Nas instituições financeiras estão disponíveis através do mercado de balcão, onde estas instituições realizam operações casadas de proteção financeira, buscando atender a demanda de seus clientes no que se refere ao tipo, valores e prazos das operações, ou seja, diferenciando-se das operações em bolsa que opera com a padronização de contratos quanto a valores e prazos. (FIGUEIREDO, 2013).

\subsubsection{Principais Mecanismos de proteção cambial no mercado de derivativos no Brasil}

O mercado de derivativos pode ser usado tanto para a proteção cambial quanto para a especulação financeira. Neste trabalho será analisado no viés de proteção cambial (hedge). Segundo Fortuna (2013, p.779), um derivativo é

um ativo ou instrumento financeiro, cujo preço deriva de um ativo ou instrumento financeiro de referência ou subjacente, e que justifica a sua existência, seja com a finalidade de obtenção de um ganho especulativo específico em si próprio, ou, e principalmente, como proteção -hedge-contra eventuais perdas no ativo ou instrumento financeiro de referência.

Este mercado permite derivar o preço de uma moeda estrangeira e proteger-se das variações do mercado de câmbio, por meio da utilização de algumas ferramentas de proteção cambial (hedge) que estão disponíveis no mercado brasileiro de derivativos para as empresas, tais como: Non-Deliverable Forward - NDF, também conhecido como termo de moeda, Opções flexíveis de moedas e Swaps.

\subsubsection{TERMO DE MOEDA}

O termo de moeda, também conhecido como Non-Deliverable Forward (NDF), é uma operação financeira de proteção cambial realizada no mercado de derivativos que possui como característica a compra ou a venda de uma moeda estrangeira numa data futura, ou seja, a fixação do câmbio para uma data futura. Uma das partes assume a posição de venda e a outra 
de compra nas mesmas condições. Nesta modalidade são necessárias garantias, como limite de crédito. Na liquidação do contrato, na data previamente acordada, ocorre o ajuste, ou seja, o empresário paga (em caso de desvalorização da taxa de câmbio) ou recebe (em caso de valorização) o valor em reais equivalente a diferença da taxa de câmbio acordada na assinatura do contrato de termo de moeda para o dia de liquidação. Segundo Figueiredo (2017, p.5):

Os principais contratos a termo, negociados no mercado brasileiro, são de dólar e de ações. Os contratos a termo de dólar, também são conhecidos no mercado como forward ou NDF (Non-deliverable forward), são muito utilizados por empresas com dívida em dólar e exportadores para se protegerem das oscilações cambiais. São negociados por essas empresas junto aos bancos.

A operação garante a trava do câmbio e a previsibilidade do custo da empresa e facilita o cálculo do preço final do produto, pois fixa o dólar. Por exemplo, se a cotação contratada no NDF for R\$3,85 por dólar americano e o custo da importação é de U\$100.000,00, a empresa poderá ter a certeza no momento da contratação do NDF que pagará futuramente R $\$ 385.000,00$ para o seu fornecedor não importando a variação cambial no período. Caso o dólar, perante o real, se valorize a $\mathrm{R} \$ 4,00$, receberá o ajuste financeiro de $\mathrm{R} \$ 15.000,00$ do NDF para pagar seu compromisso, ou seja, a diferença necessária para concluir a operação. Por outro lado, caso o dólar desvalorize a $\mathrm{R} \$ 3,70$ deverá pagar o ajuste no valor de $\mathrm{R} \$ 15.000,00$. Ao final da operação o ajuste efetuado pela operação fará com que a empresa desembolse os mesmos R \$ 385.000,00 no mercado de câmbio acordados na assinatura do contrato, garantindo assim a previsibilidade do negócio e eliminando o risco cambial.

Os NDFs podem ser realizados, no mercado brasileiro, em dólar, euro e iene. Entretanto os volumes de negociação são relevantes somente no mercado de dólar, ficando os contratos em euro e iene em segundo plano. Além disto, os contratos de euro e iene são em sua maioria sazonais muitas vezes impossibilitando a operação. Já o mercado de dólar futuro é razoavelmente robusto e possui diversas opções de contratos, subdivididos em dólar futuro e mini dólar. Ambos os contratos de NDF são diferenciados somente pelo valor dos lotes. $\mathrm{O}$ contrato padrão, na bolsa de valores, tem valor mínimo de U\$ 50.000,00 e o contrato mini tem valor mínimo de U\$ 10.000,00. (B3, 2019).

A figura 2 demostra o volume das operações de NDFs na bolsa de valores de São Paulo, historicamente conhecida como Bovespa. Pode-se perceber uma estabilidade do fluxo que se encontra na maior parte do período entre 200 bilhões de dólares e 450 bilhões de dólares ao mês. Há também certa sazonalidade conforme o calendário do agronegócio e, além disso, percebe-se uma certa estabilidade do volume de operações. 
A respeito do número de contratos disponíveis (em aberto) há uma oferta considerável disponível todos os meses do ano. Também há uma certa sazonalidade, porém sem grandes diminuições na oferta de contratos de dólar futuro, conforme demostrado no anexo 1 deste trabalho.

Figura 2 - Volume de negociações dólar futuro

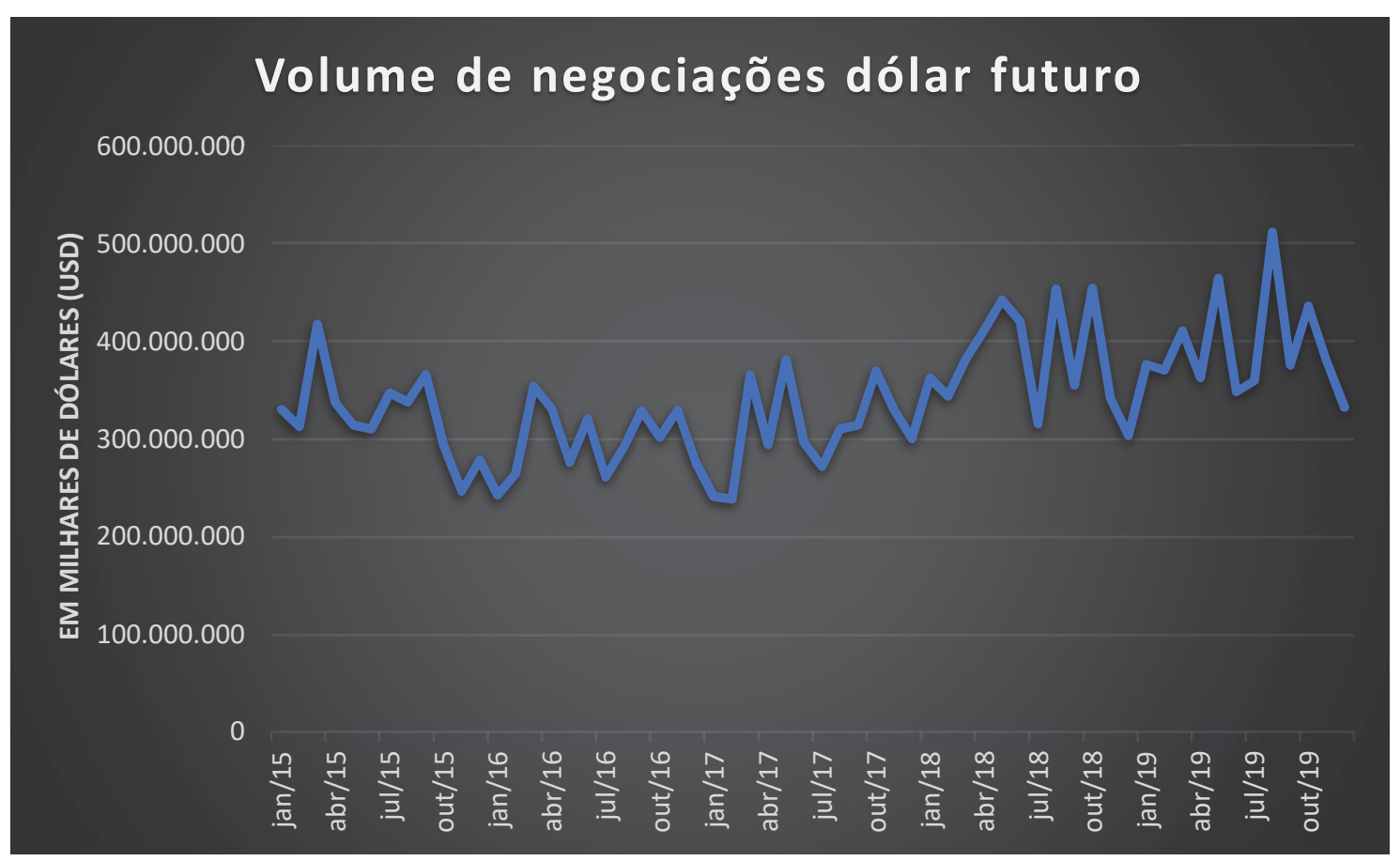

Fonte: B3, 2019

Outra forma de operar com NDF é na forma dos minicontratos padronizados na bolsa de valores, chamados de mini dólar. O contrato mínimo é de U\$10.000,00, entretanto todos os outros procedimentos são similares. Sobre sua operação incidem taxas da bolsa de valores, como emolumentos, ou seja, as mesmas taxas que são incidentes sobre os contratos a termo de dólar convencional.

Conforme a figura 3, as operações em mini dólar vêm crescendo na bolsa de valores brasileira. Desde 2015, o volume financeiro das operações cresce em exponencial, chegando ao pico de 350 bilhões de dólares em outubro de 2018, época das eleições. 
Figura 3 - Volume de negociações contrato mini dólar

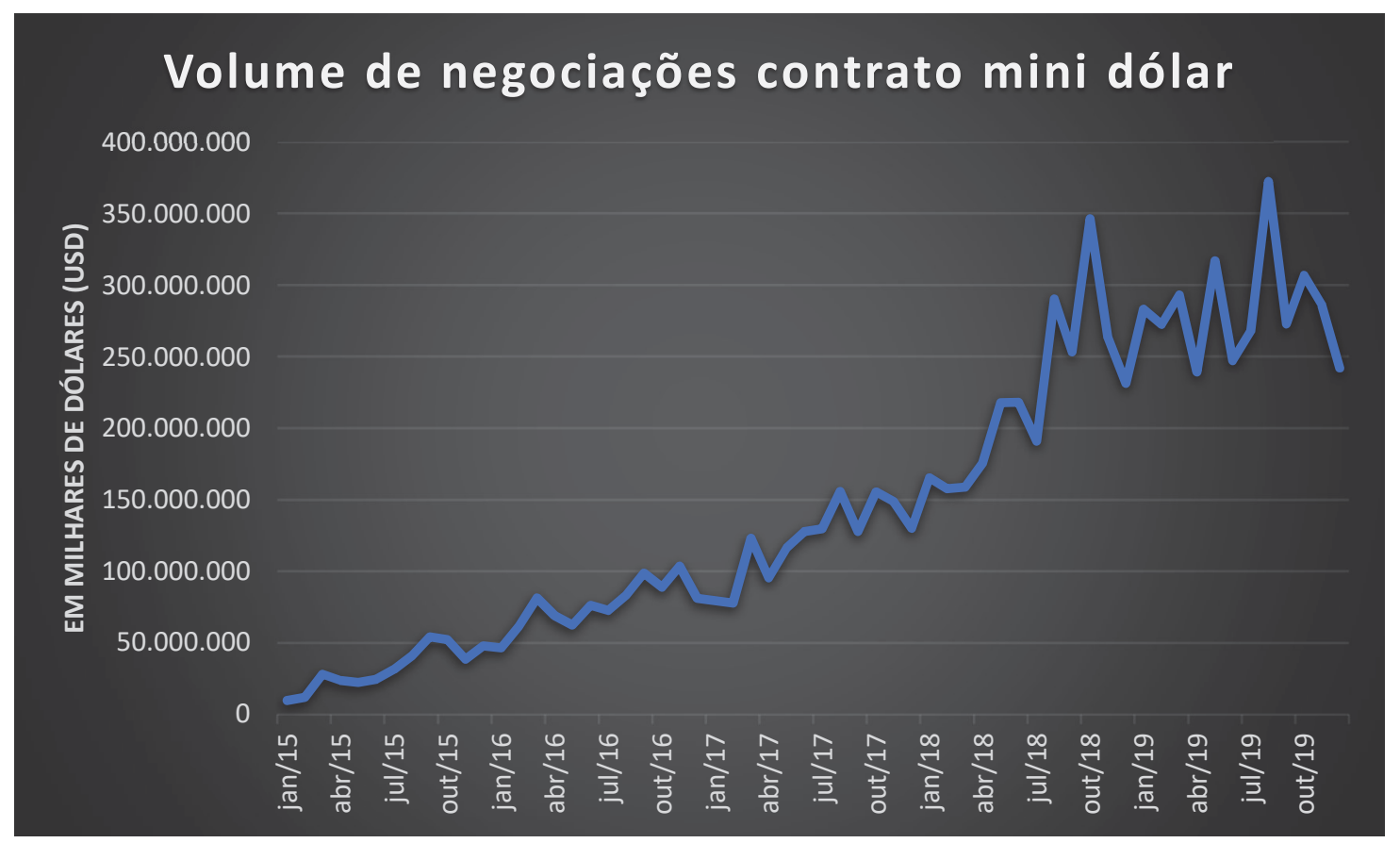

Fonte: B3, 2019.

A quantidade de contratos abertos de mini-dólar, na bolsa de valores, é variável e sazonal, porém vem demonstrando crescimento. Esta modalidade pode ser uma alternativa para o pequeno empresário conforme demostra o anexo 2 deste trabalho.

Para fins de elucidação a tabela 1 demostra uma simulação do custo de NDF. Foram considerados, para fim de análise, somente 1 lote padrão, ou seja, U\$ 50.000,00 para o NDF padrão e U\$ 10.000,00 para o mini dólar. A simulação elucida o contrato de NDF que possui nos dois casos a taxa de câmbio acordada de $\mathrm{R} \$ 3,82$. O Real brasileiro se deprecia, o que faz a taxa de câmbio subir para $\mathrm{R} \$ 4,00$. Neste caso, há um ajuste positivo de R\$ 9.000,00 no contrato de U\$50.000,00 e de R\$1.800,00 no contrato de mini dólar. Em ambos os casos é cobrado o imposto de renda de $15 \%$ sobre o ganho financeiro da operação, o que acarreta uma taxa de câmbio efetiva de $\mathrm{R} \$ 3,84$. 
Tabela 1 - Simulação de custo de NDF

\begin{tabular}{|c|c|c|c|c|}
\hline & \multicolumn{2}{|c|}{ Termo de dólar } & \multicolumn{2}{|c|}{ Mini dólar } \\
\hline Quantidades de lotes & & 1 & & 1 \\
\hline Valor do contrato (principal) & $\$$ & $50.000,00$ & $\$$ & $10.000,00$ \\
\hline Taxa de câmbio acordada (termo) & $\mathrm{R} \$$ & 3,82 & $\mathrm{R} \$$ & 3,82 \\
\hline Valor do contrato no vencimento & $\mathrm{R} \$$ & $191.000,00$ & $\mathrm{R} \$$ & $38.200,00$ \\
\hline $\begin{array}{l}\text { Taxa de câmbio PTAX no } \\
\text { vencimento }\end{array}$ & $\mathrm{R} \$$ & 4,00 & $\mathrm{R} \$$ & 4,00 \\
\hline Valor câmbio PTAX & $\mathrm{R} \$$ & $200.000,00$ & $\mathrm{R} \$$ & $40.000,00$ \\
\hline Ajuste positivo & $\mathrm{R} \$$ & $9.000,00$ & $\mathrm{R} \$$ & $1.800,00$ \\
\hline imposto de renda $(15 \%)$ & $\mathrm{R} \$$ & $1.350,00$ & $\mathrm{R} \$$ & 270,00 \\
\hline valor total do câmbio & $\mathrm{R} \$$ & $192.350,00$ & $\mathrm{R} \$$ & $38.470,00$ \\
\hline taxa de câmbio efetiva & $\mathrm{R} \$$ & 3,847 & $\mathrm{R} S$ & 3,847 \\
\hline
\end{tabular}

Fonte: Elaborado pelo autor.

\subsubsection{OPÇÕES FLEXÍVEIS}

As Opções Flexíveis são um tipo de hedge financeiro que permite fixar a cotação de uma moeda em um determinado valor, por meio da compra de opções de compra ou venda. $\mathrm{O}$ título fornece ao comprador a opção de comprar na data definida certo ativo pelo valor acordado, para tanto é necessário comprar a opção através do pagamento do prêmio. No momento do vencimento do título o comprador pode escolher se deseja ou não exercer o seu direito de compra ou de venda. (FONSECA, 2009).

Neste mercado, o lançador efetua uma oferta por tempo determinado de compra, denominada de put, ou de venda, denominada de call, ou seja ele se compromete a vender uma quantidade de certo produto, no nosso caso de uma moeda estrangeira, por determinado preço em reais brasileiros em troca de assumir este compromisso ele recebe um prêmio que é definido no momento do lançamento da oferta. O titular, aquele que compra a opção, paga o prêmio para adquirir o direito de comprar ou vender por tempo determinado a moeda estrangeira. $\mathrm{O}$ lançador fica obrigado a comprar (put) ou vender (call) o produto (moeda estrangeira) pelo valor acordado durante a duração do contrato. Entretanto, esta obrigação é concluída por meio de um ajuste financeiro, ou seja, o lançador fica obrigado a fornecer a diferença financeira necessária para comprar o produto negociado no mercado a vista no dia que o titular executar a opção. Já o titular tem a opção de comprar ou vender, ou seja, se não for benéfico para ele a operação pode optar por não a realizar e perder o valor pago de prêmio. (RICO CORRETORA DE VALORES, 2018). 
No mercado brasileiro, as opções de compra e venda são realizadas em dólar americano, pois as demais moedas não possuem um volume de negociações relevante na bolsa brasileira. De um lado está o importador que assume opção de compra (put) e do outro está o exportador ou outro agente econômico que assume opção de venda (call). A opção de compra de dólar dá o direito ao comprador de comprar dólar a uma cotação previamente acordada no momento do pagamento do prêmio, ou seja, a efetuar o câmbio pela cotação previamente acordada. Já a opção de venda de dólar dá o direito ao comprador de vender dólar a uma cotação previamente acordada no momento do pagamento do prêmio. (BANCO DO BRASIL, 2018). Neste tipo de operação o vendedor da opção fica obrigado a efetuar o ajuste do valor da cotação do dólar caso o comprador assim o deseje, ou seja, caso a cotação acordado foi R \$,00 por dólar e o dólar subir a R \$ 4,15 no caso de uma opção de compra, o vendedor da opção deverá pagar os R $\$ 0,15$ de diferença. Entretanto se o valor do dólar cair para R \$3,80, o comprador tem a opção de não efetuar a compra dos dólares pelo valor acordado e comprar diretamente a $\mathrm{R} \$ 3,80$, porém perderá o prêmio pago pela opção de compra.

Uma vantagem da opção é a possibilidade do encerramento antecipado da operação através de negociação de uma posição contrária que anule a opção anterior. Uma desvantagem é a necessidade de o lançador da opção efetuar depósito de margem para cobrir os pagamentos caso necessários. (BANCO DO BRASIL, 2018).

Os contratos padrões, na bolsa de valores, são de U\$ 50.000,00 sendo o lote mínimo 5 contratos, ou seja, compra ou venda de U\$250.000,00. Já nas opções mini os contratos padrões são de U\$ 10.000,00 e o lote mínimo de compra é 1 contrato. (B3, 2020). Entretanto o volume de negociação de contratos mini é extremamente baixo não superando 20 contratos em muitos meses e, portanto, irrelevante para os mecanismos de hedge de comércio exterior. Dessa forma, são utilizados, sobretudo, para especulação de pessoas físicas. (B3, 2019).

Conforme a figura 4, o volume de negociações de contratos de compra de dólar, ou seja, aquele usado pelos importadores para proteção cambial geralmente se mantêm em 100 bilhões de dólares e 400 bilhões de dólares. É possível perceber o aumento do número de contratos durante períodos de crise como foi 2016 pelo impeachment da então presidente Dilma Rouseff quando os valores de negociações chegaram a 800 bilhões de dólares causados pelo medo da falta de liquidez do mercado e da desvalorização do real e em janeiro de 2018 quando do início das campanhas eleitorais e a possibilidade de candidatos contrários as reformas necessárias para manter a estabilidade financeira obterem a vitória, quando os contratos chegaram aos históricos noventa e oito bilhões oitocentos e oitenta e dois milhões de dólares. Estes valores são 
expressivos, pois são operações derivativas e muitas vezes o que na prática acontece é somente o ajuste da posição.

Figura 4 - Volume de negociação opções de compra de dólar

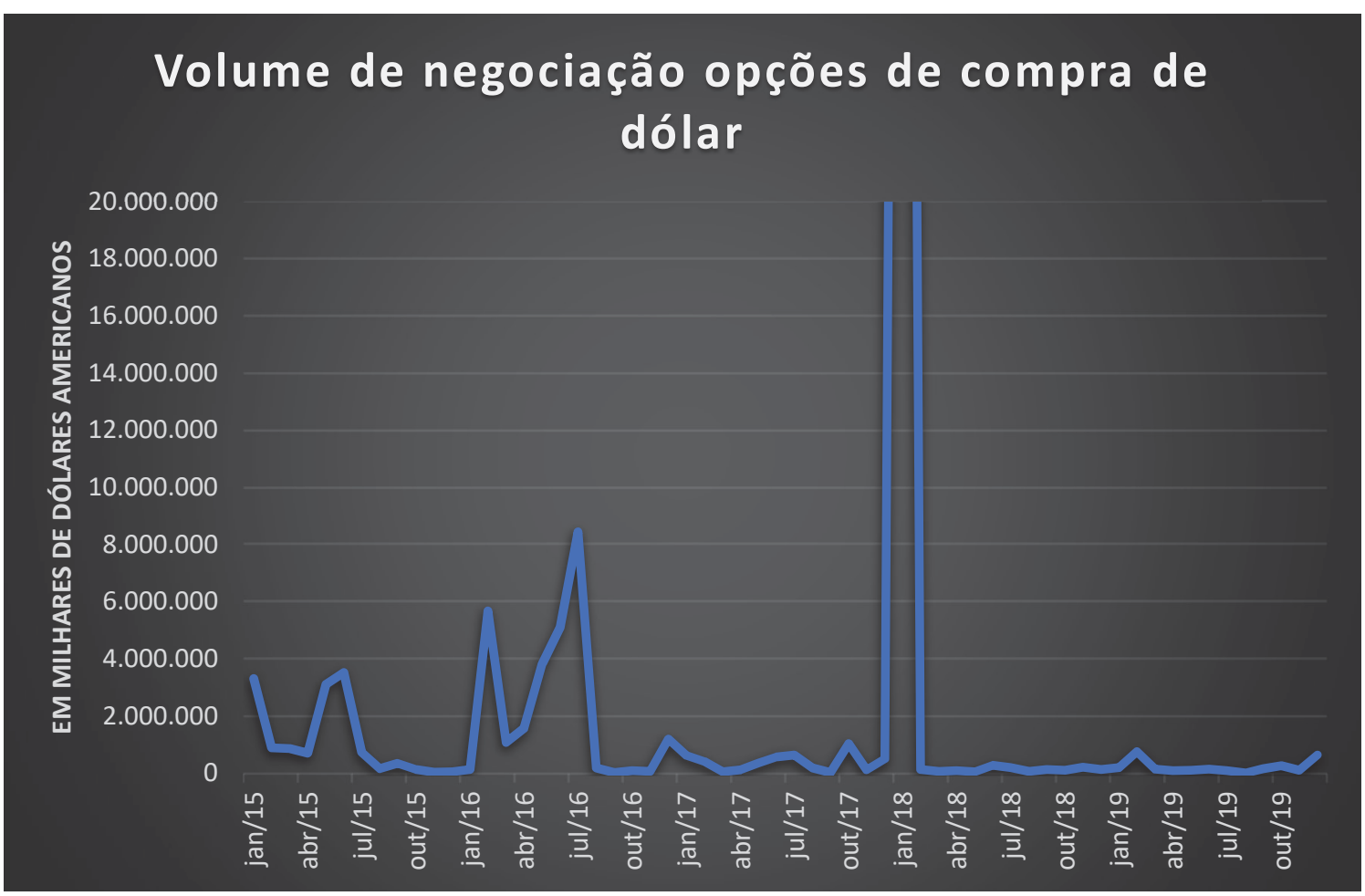

Fonte: B3, 2019.

O número de contratos de opções de compra de dólar em aberto, na bolsa de valores, por mês nos últimos 5 anos teve grande variação, somente em períodos instáveis como o impeachment em 2016 havia um número elevado de contratos disponíveis. Já em janeiro de 2018 a oferta e a demanda estavam em relativo equilíbrio. Neste período não havia muitos contratos em aberto mesmo com o alto volume de negociações. Os dados do anexo 3 deste trabalho, demostram que o mercado de opções de compra de dólares, para importadores, ainda é um mercado pouco desenvolvido no Brasil e em geral operado apenas por grandes empresas.

A figura 5 demonstra o volume de negociação das opções de venda de dólar que, assim como as opções de compra, possui um volume limitado de negociações. Em geral o volume de negociação é entre 3 bilhões e 4 bilhões de dólares. Como observado nas opções de compra, somente em períodos de instabilidade como o impeachment em 2016 e as eleições de 2018 houve grandes volumes de negociação, como em janeiro de 2018 que o volume chegou a dez bilhões duzentos e sessenta milhões de dólares americanos. 
Figura 5 - Volume de negociação de opções de venda de dólar

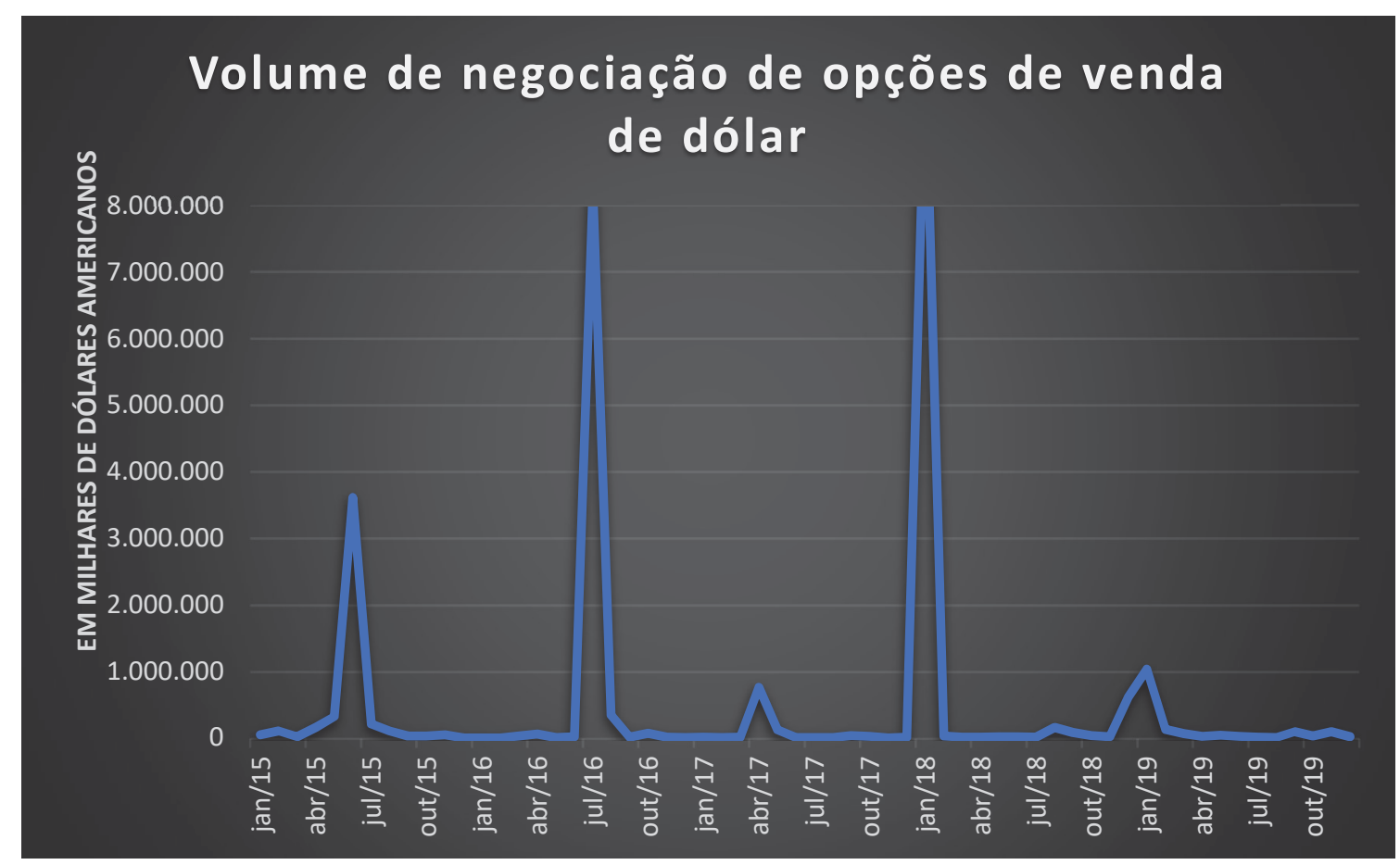

Fonte: B3, 2019.

O número de contratos abertos de opções de venda de dólares é menor que os de compra como demonstra os dados do anexo 4 deste trabalho. Em geral a média de contratos abertos por mês é de mil oitocentos e oitenta e cinco (1875). Somente em momentos de instabilidade como o impeachment em 2016 que o número de contratos disponíveis aumentou para 165 mil, o que demostra uma estabilidade nas negociações e que em geral apenas grandes empresas operam neste mercado.

As opções flexíveis se mostram como uma alternativa para proteção cambial para grandes empresas, porém o contrato mínimo de U\$250.000,00 impede que a maioria das MPEs participem deste mercado. O fluxo das operações de opções de compra e venda de dólar em geral, fora de grandes períodos de especulação, é estável demostrando a presença das grandes empresas neste mercado. Uma alternativa que foi estrutura montada pela Bovespa é o mini contrato de opções, entretanto, este mercado possui pouca liquidez, pelo número escasso de operações, o que impossibilita o seu uso de maneira segura para proteção cambial para as empresas de pequeno porte, pois este tipo de contrato ainda está muito limitado a especulação e possui pouco volume de negociação. Além disso, o mercado de mini contrato de opções é padronizado, e possui o valor mínimo de contrato de U\$ 10.000,00, o que pode possibilitar procedimentos de proteção cambial para médias empresas e algumas pequenas empresas, 
porém não para as MPEs que efetuam importações ou exportações de valores mais reduzidos. (B3, 2020).

Para fins de elucidação a tabela 2 e 3 apresentam uma simulação de uma operação de compra de opções. Entretanto é importante destacar que nesta simulação foi utilizada valores fictícios somente com fins didáticos, normalmente não sendo possível encontrar no mercado operações com variação tão significativa. Na primeira a opção é exercida e na segunda não.

Na tabela 2, foi suposta uma taxa de câmbio acordada na compra da opção de R\$ 3,00 e um prêmio de $\mathrm{R} \$ 25.000,00$ pago no ato da compra da opção. O valor do contrato é de U\$250.000,00, o que a taxa de $\mathrm{R} \$ 3,00$, seria $\mathrm{R} \$ 750.000,00$. Foi suposto neste exemplo que a taxa de câmbio no momento do vencimento da opção seria de $\mathrm{R} \$ 5,00$, ou seja, teria ocorrido uma desvalorização do real perante o dólar, o que acarretaria um pagamento de $\mathrm{R} \$ 1.250 .000,00$ para os mesmos $\mathrm{R} \$ 250.000,00$. Entretanto a opção foi exercida permitindo que a empresa comprasse U\$ $250.000,00$ por R\$ 3,00 por possuir o direito de receber o ajuste no valor de R\$ 500.000,00. Sob o ajuste incidiu o imposto de renda de $15 \%$ levando o valor total do câmbio da importação para $\mathrm{R} \$ 850.000,00$, ou seja, a taxa de câmbio efetiva foi de $\mathrm{R} \$ 4,38$.

Na tabela 3, foi suposta uma taxa de câmbio de $\mathrm{R} \$ 3,50$ para o mesmo valor e prêmio da operação da tabela 2. Entretanto a taxa de câmbio do vencimento da opção foi de $\mathrm{R} \$ 2,00$, ou seja, teria ocorrido uma valorização do real perante o dólar, o que inviabilizou o uso da opção. Nesse caso, a opção não foi exercida e a empresa "perdeu" o valor pago pelo prêmio. O custo inicial da operação calculado ao câmbio de $\mathrm{R} \$ 3,50$ era de $\mathrm{R} \$ 875.000,00$, com a diminuição do câmbio para $\mathrm{R} \$ 2,00$ o valor diminuiu para $\mathrm{R} \$ 500.000,00$, no qual adicionamos o valor de $\mathrm{R} \$ 25.000,00$ pago pelo prêmio, que foi perdido, ou seja, a taxa efetiva de câmbio foi de $\mathrm{R} \$ 2,10$. 
Tabela 2 - Opção de compra de dólar (opção exercida)

\begin{tabular}{|c|c|}
\hline & Opção de compra (Importação) \\
\hline Quantidades de lotes & 5 \\
\hline Valor do contrato (principal) & $250.000,00$ \\
\hline Taxa de câmbio acordada & 3,00 \\
\hline Prêmio Pago & $25.000,00$ \\
\hline Câmbio na taxa acordada & $750.000,00$ \\
\hline Taxa de câmbio no vencimento & 5,00 \\
\hline Valor câmbio no vencimento & $1.250 .000,00$ \\
\hline Ajuste positivo & $500.000,00$ \\
\hline Imposto de renda (15\%) & $75.000,00$ \\
\hline Valor total do câmbio & $850.000,00$ \\
\hline Taxa de câmbio efetiva & 3,40 \\
\hline Exerce a opção? & Sim, pois a cotação efetiva é menor que a taxa no vencimento. \\
\hline
\end{tabular}

Fonte: Elaborado pelo autor

Tabela 3 - Opção de compra de dólar (opção não exercida)

\begin{tabular}{|c|c|}
\hline & Opção de compra (Importação) \\
\hline Quantidades de lotes & 5 \\
\hline Valor do contrato (principal) & $250.000,00$ \\
\hline Taxa de câmbio acordada & 3,50 \\
\hline Prêmio Pago & $25.000,00$ \\
\hline Câmbio na taxa acordada & $875.000,00$ \\
\hline Taxa de câmbio no vencimento & 2,00 \\
\hline Valor câmbio & $500.000,00$ \\
\hline Ajuste & Opção não exercida. \\
\hline Exerce a opção? & Não, pois o câmbio efetivo é menor que a taxa de acordada. \\
\hline Câmbio sem exercer a opção & $525.000,00$ \\
\hline Taxa efetiva & 2,10 \\
\hline
\end{tabular}

Fonte: Elaborado pelo autor

\subsubsection{SWAPS}

O Swap é uma aplicação financeira de troca de indexadores. Este tipo de operação é muito utilizado pelo Banco Central do Brasil para estabilizar a taxa de câmbio. Porém está operação também pode ser utilizada para proteção cambial. (FIGUEIREDO, 2017).

A operação de Swap se baseia na troca de dois indexadores. As partes acordam a troca de indexador de um contrato pelo indexador de outro contrato sempre atrelado a um valor monetário, no caso do Brasil em reais. Sobre o valor base da operação as duas taxas são exercidas e no momento do resgate acontece um ajuste com o pagamento da variação. Por 
exemplo, trocar a Taxa $\mathrm{DI}^{1}$ por variação do câmbio do dólar: A empresa que possuía um contrato vinculado a variação de câmbio paga os juros advindos da taxa DI. Logo após a empresa que possuía um contrato vinculado a taxa DI paga a variação do dólar no período, ou seja, ambas empresas efetuam um ajuste mútuo. O resultado da operação para cada empresa é a soma dos débitos e créditos das duas operações, ou seja, as empresas trocam o fluxo de caixa e efetuam o pagamento na taxa que lhes é mais conveniente. (FONSECA, 2009).

Os Swaps são muito úteis quando um importador possui dívidas em dólares e recebimentos em reais e com esta situação fica exposto a sua variação. O Swap permite que o importador troque a variação do dólar pela variação da taxa DI, taxa que é mais previsível que o câmbio. Para tanto é necessário somente que um agente econômico ou empresa esteja disposta a trocar um contrato baseado na taxa DI pelo contrato baseado em dólar.

Este agente pode ser um importador que possui financiamento em dólares, ou um pagamento futuro em dólares e recebe pagamentos de seus clientes em reais. Este importador fica exposto a um alto risco cambial por possuir seu faturamento em reais e seus financiamentos e compromissos externos em dólares e, portanto certamente preferiria atrelar os seus compromissos à uma taxa DI, que por ser do mercado interno é indexada à moeda local e possui variação menor. Desta maneira não correria o risco de depreciação do real frente ao dólar e por consequência o aumento das suas dívidas. Por outro lado, um exportador com um financiamento em reais, que possui pagamentos a receber por suas operações de exportação em dólar gostaria de realizar a operação contrária trocando um financiamento atrelado a taxa DI pela taxa de câmbio de maneira a evitar as variações cambiais e efetuar o pagamento de suas dívidas diretamente com os dólares que recebe por suas exportações, possibilitando assim uma maior previsibilidade do pagamento de seus compromissos. Ambos procuram a bolsa de valores ou uma instituição financeira para realizar estas operações. (BANCO DO BRASIL, 2018).

Entretanto é geralmente com a instituição financeira que a operação terá mais liquidez, pois este intermediário financeiro efetuará operações casadas, ou seja, ao mesmo tempo que o “investidor" efetuará uma operação vinculada ao dólar outro “investidor” efetuará uma

\footnotetext{
${ }^{1}$ A taxa DI é a taxa de juros dos depósitos interbancários, ou seja, aquela utilizada em empréstimos entre as instituições financeiras. No Brasil, por segurança, nenhuma instituição financeira pode fechar o dia com caixa negativo e, portanto, as instituições superavitárias emprestam para as deficitárias ao final do dia útil. Esta operação gera a taxa DI que é calculada a partir da média dos depósitos feitos entre as instituições financeiras. Esta taxa é usada como referência para diversas operações no setor financeiro. (BIDERMAN, 2019).
} 
vinculada a taxa DI. No final do período acordado ambos os lados da operação receberão os resultados vinculados aos indexadores. (BANCO DO BRASIL, 2018).

A figura 6 demostra graficamente os contratos de Swap negociados na B3. É possível perceber que os Swaps não são muito usados no Brasil. Há tão somente uma pequena variação entre momentos de instabilidade.

Figura 6 - Contratos de Swaps DI x Dólar comercial negociados

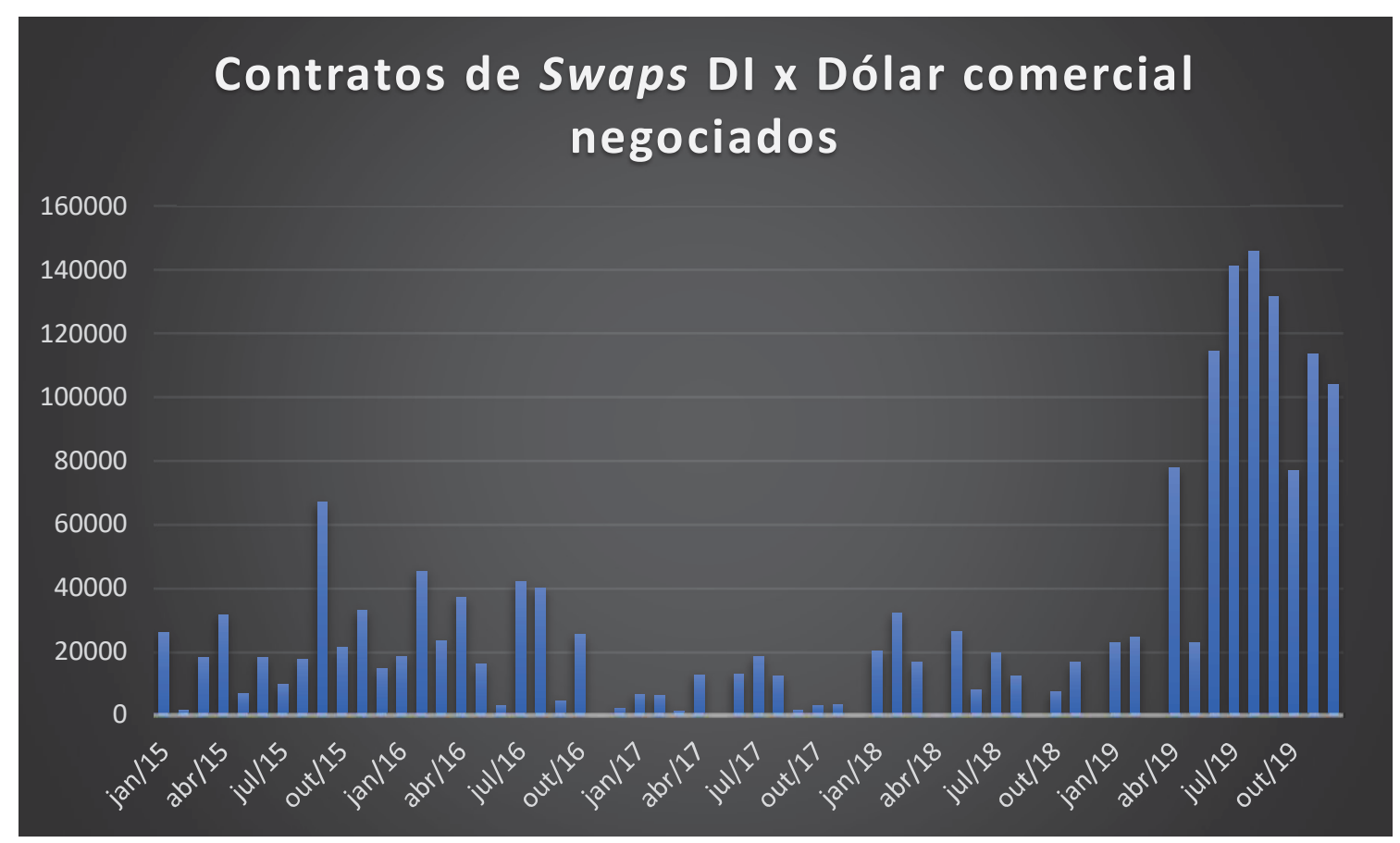

Fonte: B3, 2019

É importante destacar que estes são os contratos que o Banco Central do Brasil utiliza para controlar a variação cambial quando ela não se encontra dentro de uma variação benéfica para o país. Como em setembro de 2015 onde a moeda americana chegou a R \$4,19 (BACEN, 2015), patamar alto para aquela época.

A figura 7 demostra o volume em milhares de dólares em negociações de Swaps na bolsa de valores brasileira. O gráfico demonstra uma grande variação no volume em dólares dos Estados Unidos das transações, com diversos picos através dos anos, o que permite afirmar que o mercado de Swaps brasileiro é imprevisível. Entretanto se percebe que há uma preferência pelos Swaps em momentos de instabilidade da moeda nacional, como no período prévio as eleições de 2018, que causaram grande variação nas taxas. Em momento como estes os investidores tendem a se proteger da variação através da troca da taxa cambial pela taxa DI, porém o gráfico acima não demonstra que o Swap seja utilizado para proteção cambial do 
comércio exterior, mas sim para troca de indexadores de dívidas, ou seja, envolve mais a parte de caixa do negócio que a proteção cambial no momento de adquirir mercadorias.

Figura 7 - Volume de negociações Swaps DI x Dólar comercial

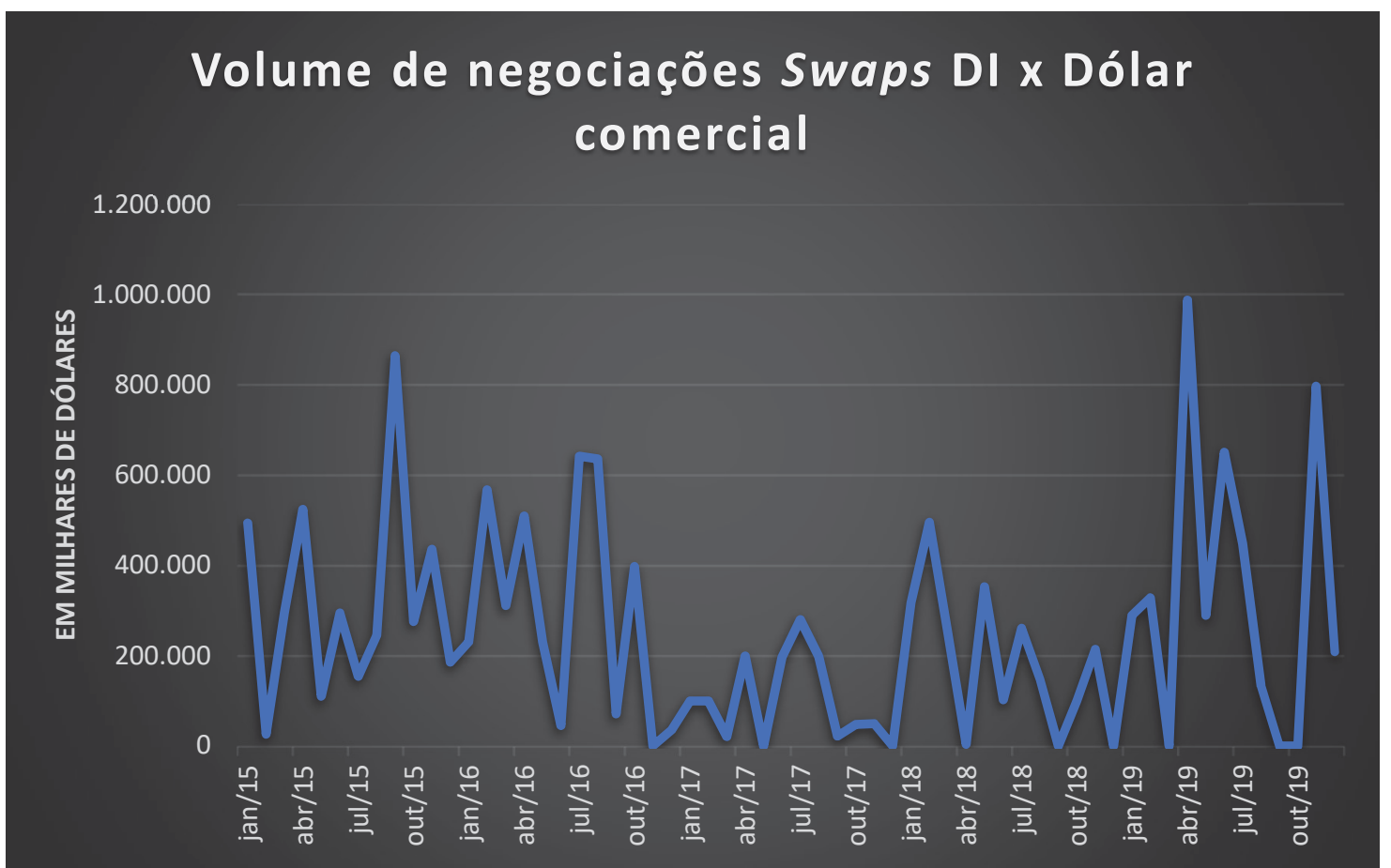

Fonte: B3, 2019

A análise efetuada nos parágrafos anteriores demostra a utilidade dos Swaps para as MPEs. As diversas trocas de indexadores possíveis com os Swaps são uma adição ao ramo de possibilidades as MPEs, porém a dificuldade de efetuar estas operações na bolsa de valores com valores menores impossibilita muitas vezes as transações das MPEs. Neste tipo de operação, o contrato com menor valor é R\$ 50 mil. (B3, 2019). Além disso, o Banco Central é o maior player deste mercado, o que cria um certo nível de incerteza quanto ao uso dos Swaps, visto que o Bacen só entra no mercado de Swaps para controlar a variação do dólar.

Outras instituições financeiras também operam Swaps, como os bancos. Fora da bolsa de valores os contratos são mais acessíveis e podem ser contratados diretamente nas agências bancárias. Entretanto os juros dos contratos em outras instituições financeiras tendem a ser mais elevados. (BANCO DO BRASIL, 2018). As MPEs devem, portanto, utilizar este tipo de mercado com cautela para evitarem prejuízos.

Para fins de elucidação a tabela 4 apresenta uma simulação de uma operação de Swap. A taxa do dólar no momento da assinatura do contrato é de $\mathrm{R} \$ 3,00$ por dólar e os juros DI 
(Taxa DI) são 6\% para o período hipotético. O valor do contrato de Swap é U\$ 50.000,00, valor que no momento da assinatura do contrato equivale a $\mathrm{R} \$ 150.000,00$. Foram analisadas quatro hipóteses de variação da taxa cambial: taxa de câmbio a $\mathrm{R} \$ 2,50, \mathrm{R} \$ 3,50, \mathrm{R} \$ 4,00$ e R $\$ 5,00$. Na segunda hipótese, o real se deprecia frente ao dólar e a taxa de câmbio aumenta para $\mathrm{R} \$ 3,50$. Neste cenário há um ajuste positivo no vencimento de $\mathrm{R} \$ 25.000,00$, pago pela empresa que possui a posição passiva, atrelada à Taxa DI, para o importador que possui a posição ativa, atrelada a cotação do dólar. Entretanto o importador assinou um contrato de Swap trocando o indexador para a Taxa DI e, considerando o contrato inicial de R $\$ 150.000,00$ submetido a juros DI de 6\% para o período, há um ajuste negativo no vencimento de $\mathrm{R} \$ 9000,00$, ou seja, o importador paga para a empresa que possui a posição passiva. Deste modo, o resultado da operação é de um pagamento pela importação de R $\$ 159.000,00$, equivalente a uma taxa de câmbio efetiva de R\$3,18. No caso de uma apreciação do real brasileiro, como na hipótese 1, há dois ajustes negativos, entretanto o valor de importação sempre continuará em $\mathrm{R} \$ 159.000,00$.

Em ambas as operações há a incidência de imposto de renda, entretanto nos Swaps o imposto de renda é variável e depende do prazo da operação. A tabela com as alíquotas aplicáveis é a regressiva e se encontra no anexo 5 deste projeto aplicado. Para facilitar o entendimento da operação como um todo o imposto de renda não foi considerado na simulação realizada na tabela 4.

Tabela 4 - Simulação de operação de SWAP Dólar comercial X Taxa DI

\begin{tabular}{|c|c|c|c|c|c|c|c|c|}
\hline \multirow[b]{2}{*}{ Evento } & \multicolumn{8}{|c|}{ Hipóteses US\$ = } \\
\hline & $\mathrm{R} \$$ & 2,50 & $\mathrm{R} \$$ & 3,50 & $\mathrm{R} \$$ & 4,00 & $\mathrm{RS}$ & 5,00 \\
\hline Pagamento de US\$50.000,00 & \multicolumn{2}{|c|}{$-R \$ 1^{2} 125.000,00$} & \multicolumn{2}{|c|}{$-R \$ 175.000,00$} & \multicolumn{2}{|c|}{$-R \$ 2^{2} 200.000,00$} & \multicolumn{2}{|c|}{-R\$ 250.000,00 } \\
\hline \multicolumn{9}{|l|}{ Resultado do Swap } \\
\hline \multicolumn{9}{|l|}{ Posição ativa (dolár) } \\
\hline Variação cambial & $-R \$$ & $25.000,00$ & $\mathrm{R} \$$ & $25.000,00$ & $\mathrm{R} \$$ & $50.000,00$ & $\mathrm{RS}$ & $100.000,00$ \\
\hline \multicolumn{9}{|l|}{ Posição passiva (taxa DI) } \\
\hline Resultado & $-R \$$ & $9.000,00$ & $-R \$$ & $9.000,00$ & $-R \$$ & $9.000,00$ & $-R \$$ & $9.000,00$ \\
\hline Resultado a receber (pagar) & $-R \$$ & $34.000,00$ & $R \$$ & $16.000,00$ & $R \$$ & $41.000,00$ & $\mathrm{R} \$$ & $91.000,00$ \\
\hline Desembolso total & $-R \$$ & $159.000,00$ & $-R \$$ & $159.000,00$ & $-R \$$ & $159.000,00$ & $-R S$ & $159.000,00$ \\
\hline Taxa efetiva & $\mathrm{RS}$ & 3,18 & $\mathrm{R} \$$ & 3,18 & $\mathrm{RS}$ & 3,18 & $\mathrm{RS}$ & 3,18 \\
\hline
\end{tabular}

Fonte: Elaborado pelo autor 


\subsubsection{Principais ferramentas de proteção cambial disponíveis no mercado de câmbio brasileiro}

O mercado de câmbio é onde ocorre a negociação, a venda e a compra de moedas estrangeiras. Este mercado é composto por pessoas físicas e jurídicas que demandam e ofertam moeda estrangeira. Segundo VIERA (2008, p.43), "o mercado de câmbio é um mercado dinâmico que envolve a negociação de moedas estrangeiras, muito dependente das políticas financeiras, fiscais, monetárias e cambiais do comércio exterior".

Segundo Fortuna (2013, p. 485), os autores que participam no mercado de câmbio estão divididos em:

os que produzem (trazem dinheiro para o país) são os exportadores, os tomadores de empréstimos e investimentos, os turistas estrangeiros e os que fazem transferência para o exterior; e os que cedem (remetem dinheiro para o exterior) são os importadores, os tomadores de empréstimos e investidores (remetem ao exterior os rendimentos do capital investido, como lucros e dividendos) e os que fazem transferência para o exterior.

O mercado de câmbio é regulado pelo Banco Central do Brasil. (BACEN, 2020). Neste mercado estão disponíveis diversas ferramentas que possibilitam hedge como: pagamento antecipado de importação, financiamento à importação, trava de importação e contratação de câmbio de importação com liquidação futura. Estas quatro ferramentas serão tratadas nesta sessão, pois podem ajudar o pequeno importador conforme podemos observar abaixo.

\subsubsection{PAGAMENTO ANTECIPADO DE IMPORTAÇÃO}

Pouco lembrado como opção de hedge pela sua simplicidade, porém o pagamento antecipado é uma maneira de realizar proteção cambial. Nesta modalidade o importador paga antecipadamente pelo produto adquirido, fixando a taxa do dia da compra e, portanto, não ficando exposto a variação cambial. Entretanto é necessário levar em conta que a mercadoria importada deve adentrar em território nacional de forma geral no prazo de 360 dias do pagamento. (SIQUEIRA, 2016).

\subsubsection{FINANCIAMENTO À IMPORTAÇÃO}

O financiamento à importação (Finimp) permite ao importador, através de uma instituição financeira de seu relacionamento, a realização de financiamento de suas importações em moeda estrangeira. O pagamento por sua vez é enviado pela instituição financeira financiadora diretamente ao exportador que recebe o valor à vista. (BORGES, 2012). 
Esta modalidade de financiamento é um tipo de empréstimo e, portanto, deve se levar em conta que é necessário limite de financiamento disponível na instituição financeira de relacionamento da MPEs. Além disso, por se tratar de um "empréstimo" incidem taxas de juros, entretanto as taxas aqui aplicadas são aquelas do mercado internacional, como a Libor $^{2}$, que são relativamente inferiores as praticadas no mercado nacional. (BORGES, 2012).

\subsubsection{CONTRATAÇÃO DE CÂMBIO DE IMPORTAÇÃO COM LIQUIDAÇÃO FUTURA}

O câmbio futuro é uma operação financeira, contratada junto as instituições financeiras, que permite a trava da taxa de câmbio na assinatura do contrato. Esta operação permite o fechamento de câmbio para uma data futura, ou seja, a empresa contratante saberá no momento da assinatura do contrato a taxa de câmbio que será utilizada futuramente. Na assinatura do contrato, o importador entrega os reais correspondentes aos dólares pela taxa do dia. A instituição financeira efetua o pagamento ao fornecedor, em moeda estrangeira, na data acordada. (ATSUMI, 2009).

A operação de câmbio com liquidação futura está disponível nos bancos comerciais por meio da utilização do limite de crédito aprovado junto a estas instituições. Além disso, a operação fica limitada a legislação vigente no momento da assinatura do contrato e, portanto, não é possível antecipar o pagamento de uma importação por período superior a 360 dias. (SIQUEIRA, 2016).

\subsubsection{TRAVA DE CÂMBIO}

A Trava de câmbio é uma operação financeira que permite fixar a taxa de câmbio previamente junto a uma instituição financeira. Possui prazos de até 360 dias. Difere da operação anterior pelo fato de os reais correspondentes aos dólares da operação não serem entregues no momento da contratação do contrato, mas somente na liquidação junto ao exterior. (SIQUEIRA, 2016).

A trava de câmbio é geralmente utilizada por exportadores que pretendem fixar os seus recebimentos futuros, mas pode também ser utilizada pelos importadores de maneira a utilizar o câmbio atual no futuro através da troca da taxa pelo indexador, ou seja, incidirá juros, sobre o montante em reais, vinculados ao CDI. Entretanto mesmo que a operação envolva juros a

\footnotetext{
${ }^{2}$ A Libor é a taxa depósitos interbancários do Reino Unido. Utilizada pelas instituições financeiras do mercado londrino para empréstimos mútuos. Ela é vinculada a libra esterlina e a outras cinco moedas internacionais. Além disso, é utilizada como referência para vários contratos no mercado internacional. (BANK OF ENGLAND, 2018).
} 
mesma não é considerada um financiamento e sim uma operação de proteção cambial, não sendo necessário o adiantamento de valores ao banco. Porém como se trata de operação financeira o importador necessita de crédito aprovado para realizar a operação. Além disso, o importador deve apresentar toda a documentação pertinente ao banco de maneira a provar que a operação será utilizada para fins de comércio exterior. Por fim, o importador corre o risco de ter que pagar multas e taxas se a operação de entrada da mercadoria atrasar ou a sua importação for cancelada de maneira a cancelar ou postergar a operação financeira. (BANCO BRADESCO, 2019).

\subsubsection{Principais produtos bancários disponíveis}

Os produtos bancários são aqueles produtos oferecidos pelas instituições financeiras. Os bancos atuam como intermediários nestas operações, intermediando as relações dos agentes superavitários (captação) e deficitários (tomadores de empréstimo) do sistema financeiro e oferecendo produtos financeiros, como investimentos $\mathrm{e}$ as mais diversas operações. (CAMARGO, 2009). Entre estes produtos há algumas opções que possibilitam o hedge cambial, como o Fundo Cambial e a abertura de uma conta corrente em moeda estrangeira no exterior, que serão tratados nesta sessão.

\subsubsection{FUNDO CAMBIAL}

O fundo cambial é um produto financeiro não operacionalizado no mercado de câmbio brasileiro. É um fundo de investimentos atrelado a flutuação de uma moeda estrangeira. Este tipo de fundo pode ser utilizado como maneira de proteção cambial, pois possui como característica o investimento de, pelo menos, $80 \%$ de seu patrimônio líquido em ativos atrelados a moedas estrangeiras. Geralmente estes tipos de fundo acompanham a cotação de uma moeda, ou seja, há ganhos de capital quando a moeda estrangeira se valoriza e perdas quando ela se desvaloriza. (FORTUNA, 2013).

Os fundos cambiais estão disponíveis tanto em bancos tradicionais como em corretoras e, no Brasil, geralmente são atrelados a variação do dólar comercial. Possuem como vantagens ao exportador ou importador que deseja efetuar proteção cambial:

a) o baixo valor inicial necessário para a aplicação;

b) fácil acompanhamento da flutuação da taxa de câmbio durante o período vigente da aplicação no fundo; e

c) a liquidez, muitas vezes diária 
O fundo cambial se mostra como boa opção para empresas que desejam efetuar proteção cambial e não desejam aprofundar os seus conhecimentos no mercado financeiro, pois estes fundos efetuam investimentos nos derivativos mencionados anteriormente, como opções, contratos de compra e venda de dólar, etc. Como o fundo conta com a administração de um gestor especializado no mercado ele é mais simples de operar. Por fim, este tipo de fundo possui grande liquidez, muitas vezes diária, e seus saques e aportes são feitos em reais, facilitando ainda mais sua operação. (XP INVESTIMENTOS, 2019).

\subsubsection{CONTA NO EXTERIOR}

Ao analisarmos o setor externo da economia brasileira, um dos maiores avanços no quesito de câmbio ocorreu março de 2008. Este avanço foi a possibilidade de manutenção de $100 \%$ dos recursos de exportação no exterior em moeda estrangeira, conforme resolução $\mathrm{n}^{\text {o }}$ 3548 do conselho monetário nacional de 2008. (CONSELHO MONETÁRIO NACIONAL, 2008).

Essa norma introduziu no âmbito brasileiro a possibilidade inédita de manter os recursos recebidos em moeda estrangeira advindos de exportações em conta no exterior para pagamento de importações, diretamente desta conta no exterior, ou seja, sem a necessidade de contratação de câmbio de exportação e de importação no Brasil. (CONSELHO MONETÁRIO NACIONAL, 2008).

\subsubsection{Imposto de renda sobre as operações de proteção cambial}

As operações descritas neste projeto aplicado são consideradas, em sua maioria, aplicações financeiras. Esta classificação de aplicação financeira acarreta o recolhimento de imposto de renda quando ocorrer "lucros", ou seja, deve-se recolher impostos sobre os reajustes positivos que vierem a ocorrer durante as operações. (RECEITA FEDERAL DO BRASIL, 2020).

O recolhimento de imposto de renda causa, para o importador, um aumento da taxa de câmbio efetiva, pois parte do valor financeiro da proteção em operações nos mercados de derivativos e bancário acaba sendo paga em impostos. Entretanto estas operações ainda possibilitam a realização de hedge e são vantajosas para as empresas, pois a variação cambial é evitada. (BANCO DO BRASIL, 2018). As tributações dos rendimentos das operações com mecanismos de proteção cambial são, em geral, 15\% sobre o "lucro", ou seja, quando há 
prejuízo nas operações por ajuste negativo não é cobrado imposto de renda. Os NDFs, por exemplo, têm o valor de seus ajustes positivos taxados em $15 \%$.

As operações de opções flexíveis, quando executadas, também estão sujeitas a impostos que devem ser pagos quando há ajuste positivo. Sobre esta diferença incide o imposto de 15\%. (BANCO DO BRASIL, 2018).

Os Swaps também estão sujeitos ao imposto de renda quando apresentarem resultado positivo, entretanto este tipo de operação está sujeito a tabela regressiva, ou seja, quanto maior for a duração da operação menor o imposto incidente sobre o resultado financeiro podendo chegar a 15\% em aplicações superiores a 720 dias, conforme ilustrado no anexo 5 deste trabalho. (BANCO DO BRASIL, 2018).

Os fundos cambiais possuem imposto retido em fonte no momento do saque, ou seja, quando há ganho de capital através destes tipos de fundo, há incidência de imposto de renda na fonte calculado através da tabela regressiva. Além disso, por se tratar de fundo de investimentos há uma taxa de administração anual que deve ser levada em conta na hora de efetuar a aplicação com o objetivo de hedge cambial, estas taxas variam de fundo para fundo. (BTG PACTUAL, 2020).

Por fim, no mercado de câmbio há outros tipos de impostos incidentes sobre as operações. No momento de realizar a operação de câmbio há incidência de Imposto sobre operações financeiras (IOF), por exemplo. Estes impostos devem ser consultados previamente a contratação das operações, pois podem ser modificados sem aviso prévio. (RECEITA FEDERAL DO BRASIL, 2019). 


\section{MÉTODO}

\subsection{CLASSIFICAÇÃO DA PESQUISA}

Esta pesquisa constituiu-se por um estudo de caso expositivo, com abordagem qualitativa, com o objetivo de recolher dados sobre a percepção das operações de hedge financeiro de MPEs, pesquisando aspectos motivacionais para a contratação destas operações, o conhecimento sobre as mesmas e a percepção da utilidade destas operações pelas MPEs e a visão das instituições financeiras. O estudo pretendeu elucidar a percepção dos empresários sobre as operações de proteção financeira disponíveis, a satisfação dos pequenos empresários com a oferta deste tipo de operação e a visão dos bancos sobre as operações de hedge voltadas aos pequenos empresários. Segundo Yin (2009, p.32):

o estudo de caso é um método de pesquisa que utiliza, geralmente, dados qualitativos, coletados a partir de eventos reais, com o objetivo de explicar, explorar ou descrever fenômenos atuais inseridos em seu próprio contexto. Caracteriza-se por ser um estudo detalhado e exaustivo de poucos, ou mesmo de um único objeto, fornecendo conhecimentos profundos.

A pesquisa qualitativa se caracteriza pela utilização dos dados dedutivos. É utilizada para identificar significados mais abrangentes que não podem ser identificados através de estatísticas, como a percepção do entrevistado sobre um tema, valores, etc. Ela prioriza uma maior interpretação dos dados envolvendo os motivos e atitudes relacionadas (CRESWELL, 2010).

\subsection{POPULAÇÃO E AMOSTRA}

A pesquisa envolveu três colaboradores do setor cambial e business de bancos comerciais públicos e três micro e pequenos empresários que possuem importação e/ou exportação frequentes dos mais diversos mercados mundiais. Todos os empresários têm suas sedes em Porto Alegre, os colaboradores dos bancos são de Santa Maria, Caxias do Sul e Porto Alegre e todos foram indicados por profissionais da área de comércio exterior.

A tabela 5 apresenta as características dos micros e pequenos empresários e funcionários de bancos. 
Tabela 5 - Caracterização dos entrevistados

\begin{tabular}{|r|l|l|l|}
\hline Entrevistado & Ramo & $\begin{array}{l}\text { Mês e ano de } \\
\text { aplicação do } \\
\text { questionário }\end{array}$ & Cargo \\
\hline $\mathbf{1}$ & Banco comercial público & Janeiro/2020 & Analista de câmbio \\
\hline $\mathbf{2}$ & Banco comercial público & Dezembro/2019 & Gerente \\
\hline $\mathbf{3}$ & Banco comercial público & Dezembro/2019 & $\begin{array}{l}\text { Gerente de Negócios } \\
\text { Internacionais }\end{array}$ \\
\hline $\mathbf{4}$ & $\begin{array}{l}\text { Pequena empresa de varejo no ramo de } \\
\text { iluminação }\end{array}$ & Abril/2020 & Empresário \\
\hline $\mathbf{5}$ & $\begin{array}{l}\text { Pequena empresa de varejo do ramo de } \\
\text { moda e guarda-chuvas }\end{array}$ & Janeiro/2020 & Empresário \\
\hline & $\begin{array}{l}\text { Pequena empresa de varejo no ramo de } \\
\text { vestuário }\end{array}$ & Janeiro/2020 & Empresário \\
\hline & & & \\
\hline
\end{tabular}

Fonte: elaborado pelo autor

Todos os empresários questionados neste projeto aplicado possuem MPEs. Para efetuar este enquadramento foram utilizados os critérios do Sebrae, que definem como micro e pequenas empresas, no setor de comércio e serviços, aquelas que possuem até 49 empregados e faturamento bruto anual até R $\$ 4.8$ milhões, caso de todas as empresas analisadas neste projeto aplicado. (SEBRAE, 2020).

A tabela 6 apresenta a definição de porte de estabelecimentos segundo o número de empregados. Ela se encontra subdividida nos setores de comércio e serviços e indústria. As classificações de porte estão subdivididas em microempresa, empresa de pequeno porte, empresa de médio porte e grandes empresas. (SEBRAE, 2020) 
Tabela 6 - Classificação de porte dos estabelecimentos segundo número de empregados

Definição de porte de estabelecimentos segundo o número de empregados

\begin{tabular}{|c|c|c|}
\hline Porte & Comércio e Serviços & Indústria \\
\hline Microempresa (ME) & Até 9 empregados & Até 19 empregados \\
\hline Empresa de Pequeno Porte (EPP) & De 10 a 49 empregados & De 20 a 99 empregados \\
\hline Empresa de médio porte & De 50 a 99 empregados & De 100 a 499 empregados \\
\hline Grandes empresas & 100 ou mais empregados & 500 ou mais empregados \\
\hline
\end{tabular}

Fonte: Sebrae, 2013

O quadro 1 apresenta a definição de porte dos estabelecimentos segundo a receita bruta. Microempresas são aquelas que possuem receita bruta anual até R\$360.000 e Empresas de pequeno porte aquelas com receita bruta anual superior a $\mathrm{R} \$ 360.000$ e inferior a $\mathrm{R} \$ 4.800 .000$.

Quadro 1 - Classificação de porte dos estabelecimentos segundo a receita bruta

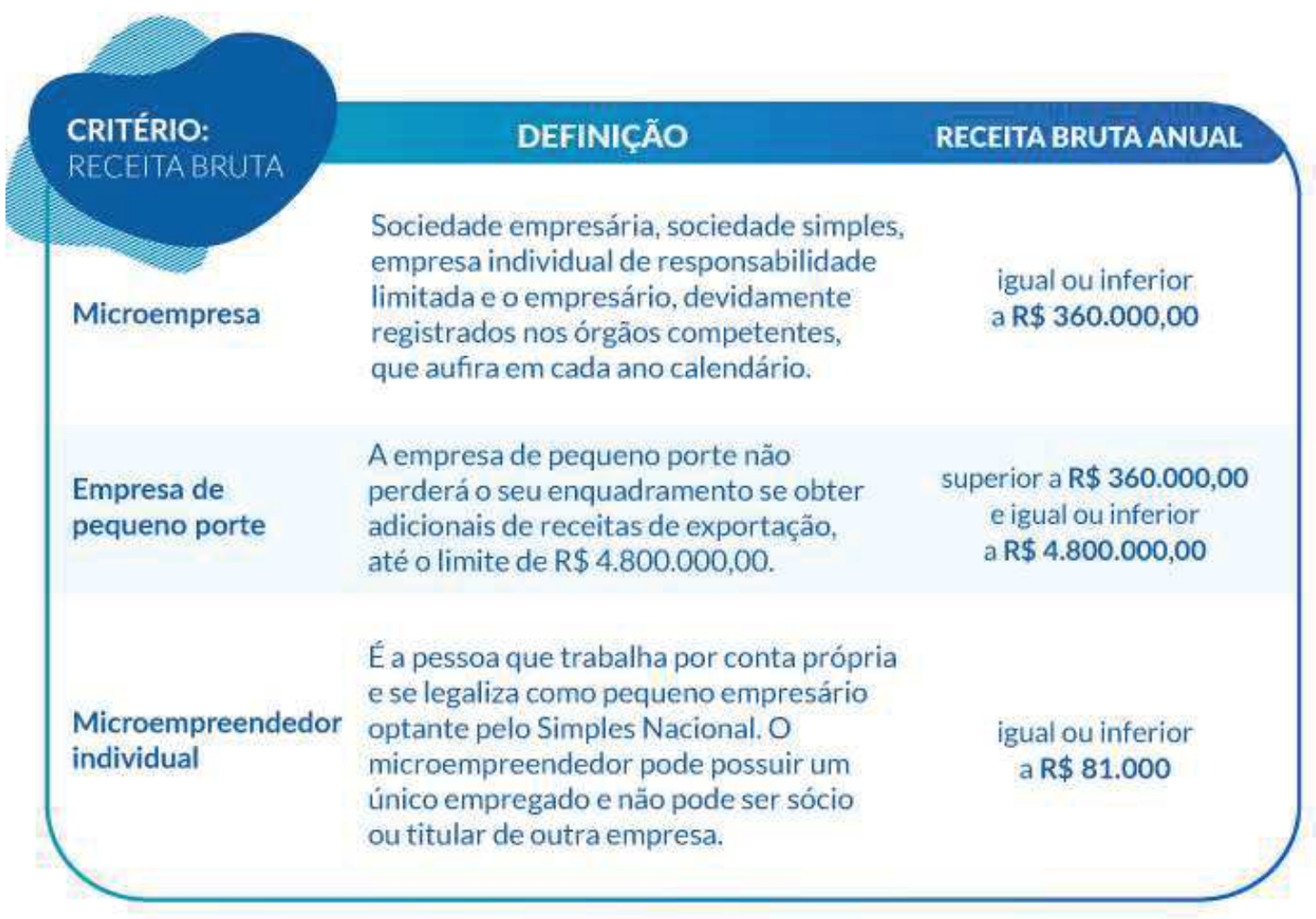

Fonte: Sebrae, 2006. 


\subsection{COLETA DE DADOS}

Os dados coletados durante esta pesquisa foram classificados como primários e secundários. A coleta de dados primários foi efetuada através de entrevista semi-estruturada, enquanto os dados secundários foram coletados através de pesquisa bibliográfica expositiva apresentada no referencial teórico deste trabalho.

Para ampliar o conhecimento sobre o assunto, foi realizada uma pesquisa expositiva em diversas fontes de dados secundárias como, pesquisa documental, bases de dados nacionais e internacionais, dados de bolsas de valores, leis de comércio exterior, artigos relevantes sobre o tema e livros de autores conceituados e reconhecidos junto a academia.

A entrevista semi-estruturada está focalizada em um assunto sobre o qual confeccionamos um roteiro com perguntas principais, complementadas por outras questões que surgiram durante a condução da entrevista permitindo uma maior participação do entrevistado na elaboração do trabalho. Este tipo de entrevista pode fazer emergir informações de forma mais livre e as respostas não estão condicionadas a uma padronização de alternativas. (MANZINI, 2018).

O roteiro de entrevista foi aplicado através de dois questionários. Cada questionário foi elaborado com o foco no público alvo ao qual foram aplicados. O primeiro questionário possui perguntas com foco técnico e operacional, e foi aplicado a funcionários dos bancos. O segundo questionário possui perguntas gerais e sobre o dia a dia das operações de importação e exportação dos empresários e foi aplicado junto aos pequenos empresários anteriormente caracterizados. Ambos os questionários possuem dez questões. ${ }^{3}$

Os participantes foram contatados por e-mail e telefone de forma consecutiva de agosto de 2019 a abril de 2020. Durante os diversos contatos com os entrevistados foi incentivado a adição de novos pontos que os participantes considerassem relevantes de modo a permitir o surgimento de novos focos de pesquisa e a adição de operações de proteção cambial ao presente projeto.

\footnotetext{
${ }^{3}$ Os roteiros com as questões aplicadas durante as entrevistas estão disponíveis no apêndice III e IV para consulta. Entretanto ressaltasse que estão disponíveis somente as questões iniciais e que outras questões foram levantadas de forma expontânea.
} 


\subsection{ANÁLISE DE DADOS}

Após a coleta de dados foram efetuadas as etapas da análise e interpretação das informações coletadas. A análise e interpretação dos dados são o cerne da pesquisa qualitativa - embora sua importância seja vista sob diferentes aspectos nas diferentes abordagens (FLICK, 2004). Na sequência, foi efetuado a separação do material em categorias mais relevantes de maneira a organizar e proporcionar as respostas aos objetivos propostos neste projeto aplicado.

A separação em categorias se faz necessário, segundo GIL (1987), pois as respostas fornecidas tendem a ser mais variadas. Para que as respostas possam ser analisadas e relacionadas corretamente é necessário organizá-las, o que é feito em categorias. As categorias utilizadas no presente estudo foram: amostra, conhecimento sobre proteção cambial, acesso à informação sobre as operações disponíveis, operações utilizadas, operações de hedge (derivativos) na bolsa de valores e dificuldades dos micros e pequenos empresários.

Os dados coletados durante as entrevistas foram correlacionados com a revisão de literatura e a partir deles dedutivamente. Por meio da análise dos resultados das entrevistas, relacinaram-se as visões dos bancos sobre as operações de proteção cambial com as visões dos empresários. O foco da análise de dados foi evidenciar as percepções convergentes e divergentes dos dois lados envolvidos nas operações, para tanto, os dados das entrevistas foram separados por categorias de análise e confrontados com os dados expostos no referencial teórico para tornar possível a resposta dos objetivos deste projeto aplicado.

Por fim, o método utilizado para análise dos dados deste projeto aplicado possui limitações por se tratar de um método generalista e dedutivo. Segundo Matar, a pesquisa exploratória não se trata de um estudo conclusivo, pois ela aprofunda o conhecimento do assunto e gera hipóteses explicativas e deduções baseados nos dados como entrevistas. (MATTAR, 2012).

Os dados apresentados no presente projeto aplicado foram coletados de fontes confiáveis, como órgãos governamentais, dados estatísticos de operações da bolsa de valores, entrevistas com empresários do ramo e bancos conceituados no Brasil. Além disso, procurouse utilizar os dados mais recentes disponíveis. Entretanto não é possível afirmar que todos os dados disponíveis sobre o assunto foram analisados, pois o objetivo deste trabalho é somente fornecer uma visão mais ampla sobre as operações e a situação do mercado de proteção cambial para as pequenas empresas. Além disso, algumas das operações expostas neste trabalho são complexas e foram explicadas parcialmente somente para o leitor tomar conhecimento das 
mesmas e devem ser analisadas mais profundamente antes de ser utilizadas pelas empresas. Por fim, informações adicionais e novas operações podem ser descobertas a qualquer tempo não sendo possível inserir todas disponíveis, mas somente as mais relevantes.

O método qualitativo de pesquisa também possui as suas limitações por não ser baseados em dados estatísticos e sim nas percepções dos entrevistados. Sendo assim este método pode conter evidências equivocadas, pois está sujeito ao erro humano. Segundo YIN (2015), não há processos rigorosos a serem seguidos nesta metodologia, podendo ocasionar a utilização de evidências equivocadas que podem influenciar diretamente o resultado da pesquisa. Além disso, os estudos de caso expandem e generalizam teorias por serem baseados em um conjunto múltiplo de elementos sob condições diferentes. 


\section{RESULTADOS DA PESQUISA}

Esta sessão do projeto aplicado se dispõe a apresentar os resultados da pesquisa realizada com empresários em instituições financeiras sobre a utilização de hedge cambial. Ao analisar as empresas através de questionário as questões tiveram o foco na percepção do empresário e sua familiaridade com as operações de proteção cambial. Já ao analisar os bancos procurou-se manter o foco da percepção que os bancos possuem dos clientes (empresários), da demanda de operações de pequenas empresas e as principais dificuldades que os empresários possuem ao procurar estas operações.

\subsection{A AMOSTRA}

Neste estudo, os empresários questionados se dividem em: aqueles que trabalham somente com importação, aqueles que trabalham somente com exportação e aqueles que trabalham tanto com importações como exportações. Todos os empresários entrevistados possuem pequenos negócios, ou seja, estão enquadrados como micro e pequenas empresas. Pode-se visualizar a divisão da amostra na figura 8 .

Figura 8 - Tipo de operação de comércio exterior realizada pelas empresas

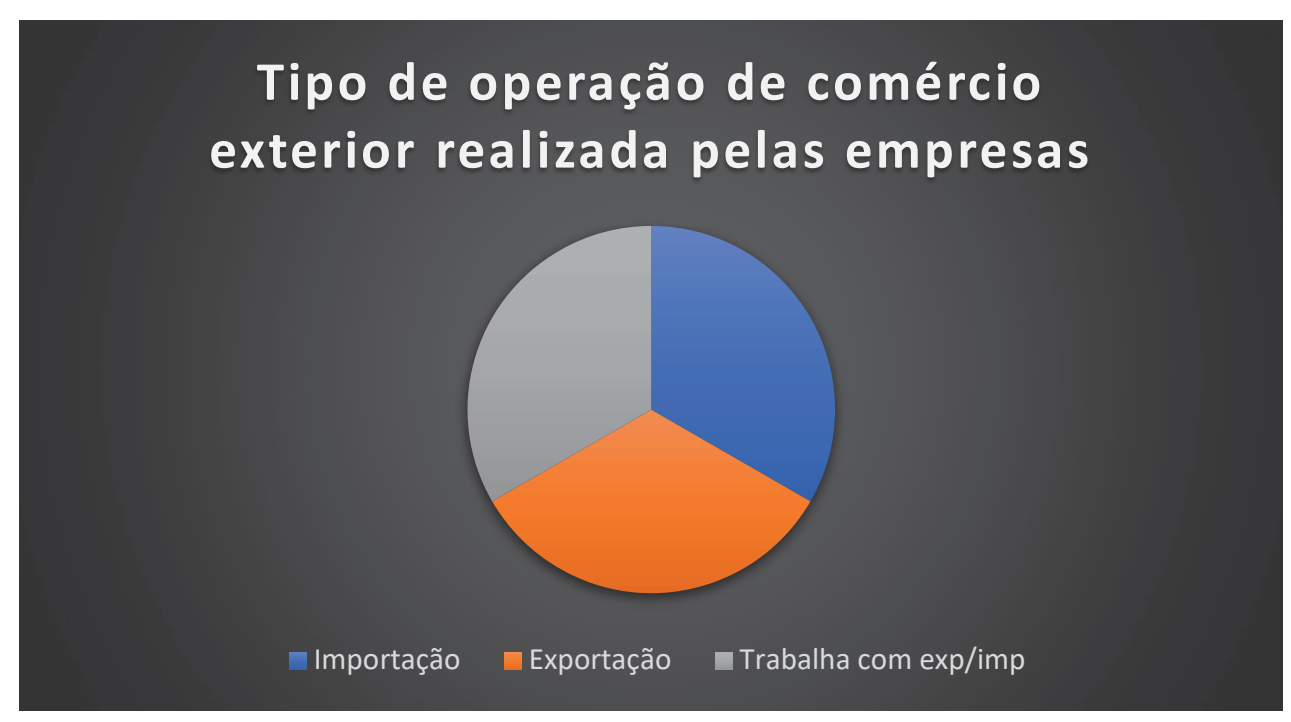

Fonte: Elaborado pelo autor

Considerando os integrantes do setor bancário que foram entrevistados, estes foram mais homogêneos. Todos os integrantes deste setor, que foram entrevistados, são ligados a bancos públicos com status de sociedade mista. 


\subsection{O CONHECIMENTO DOS AGENTES SOBRE PROTEÇÃO CAMBIAL}

O conhecimento sobre as operações de proteção cambial dos empresários foi analisado sobre o ponto de vista dos bancos e sobre o ponto de vista dos empresários. Conforme a figura 9, 1/3 dos empresários entrevistados acredita que não possui conhecimento, 1/3 acredita possuir conhecimento intermediário e 1/3 acredita possuir conhecimento intermediário pra bom sobre as operações.

Figura 9 - Autoavaliação dos empresários em relação aos conhecimentos das operações de hedge

\section{Autoavaliação dos empresários em relação aos conhecimentos das operações de hedge}

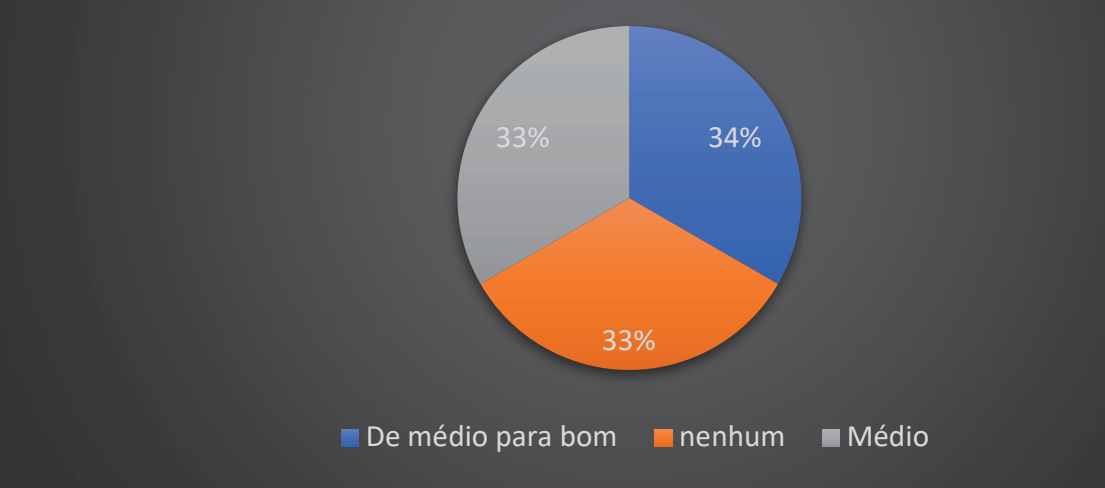

Fonte: Elaborado pelo autor

Conforme a figura 10, a percepção dos bancos é que o conhecimento dos micros e pequenos empresários sobre as operações de hedge é superficial ou inexistente na maioria das empresas deste porte. Além disso, conforme os entrevistados o importador possui maior conhecimento que exportador, pois a variação cambial afeta-os com maior intensidade que os exportadores. 
Figura 10 - Percepção das instituições financeiras sobre o conhecimento dos empresários das operações de hedge

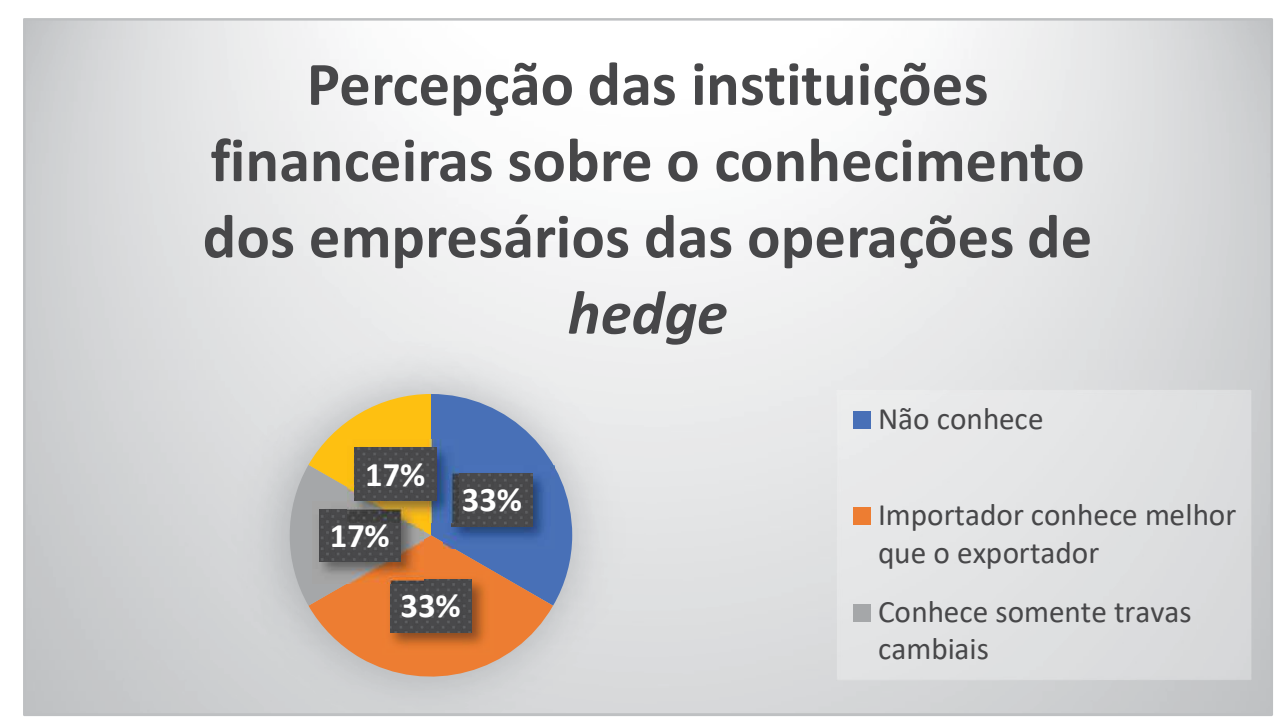

Fonte: Elaborado pelo autor

Considerando o conhecimento das operações a afirmação dos bancos de que o importador conhece mais que o exportador se confirma, pois os empresários que afirmaram possuir conhecimento mais aprofundado das operações trabalham com importação ou conjuntamente, com exportação e importação. Entretanto quando questionados sobre as operações utilizadas por suas empresas estes mesmos empresários citam mais procedimentos do mercado de câmbio do que do mercado de balcão.

\subsection{O ACESSO À INFORMAÇÃO SOBRE AS OPERAÇÕES DISPONÍVEIS}

Considerando a acessibilidade as informações, empresários e analistas dos bancos possuem posições inversas. Conforme a figura 11, os empresários em sua maioria (67\%) acreditam que não há acesso suficiente a informação sobre as operações. Somente $33 \%$ acredita que há informação suficiente sobre as operações que poderiam ajudar os micros e pequenos empresários. Além disso, alguns dos entrevistados citaram que o banco nunca lhes ofereceu opções de contratos de hedge disponíveis para seu negócio e alguns acreditam que os funcionários dos bancos que atendem os pequenos negócios não estão suficiente preparados para oferecer este tipo de operação. 
Figura 11 - Acessibilidade à informação sobre operações de hedge segundo os empresários

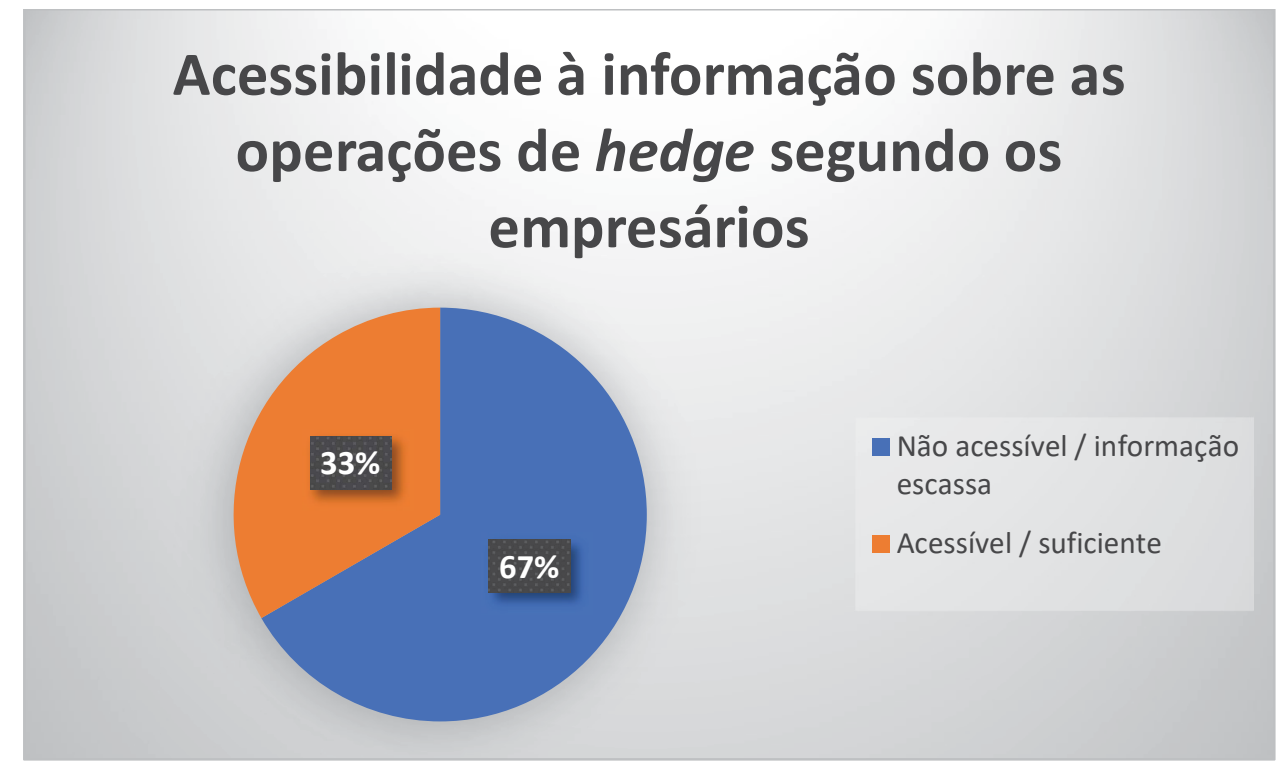

Fonte: Elaborado pelo autor

Conforme a figura 12, a percepção dos bancos é oposta à dos empresários. Segundo os funcionários dos bancos, as informações sobre proteção financeira são ressaltadas em conversas com os empresários, realizadas pelos gerentes de relacionamento e pelo gerente da agência da conta corrente. Entretanto um dos entrevistados reconheceu que a divulgação é escassa e que os funcionários que deveriam oferecer estas operações muitas vezes não possuem conhecimento satisfatório sobre as mesmas. Além disso, foi citado pelos entrevistados que muitas vezes a falta de interesse dos empresários por este tipo de operações impede a abordagem do tema por parte das instituições financeiras. 
Figura 12 - Acessibilidade à informação sobre as operações de hedge segundo os bancos

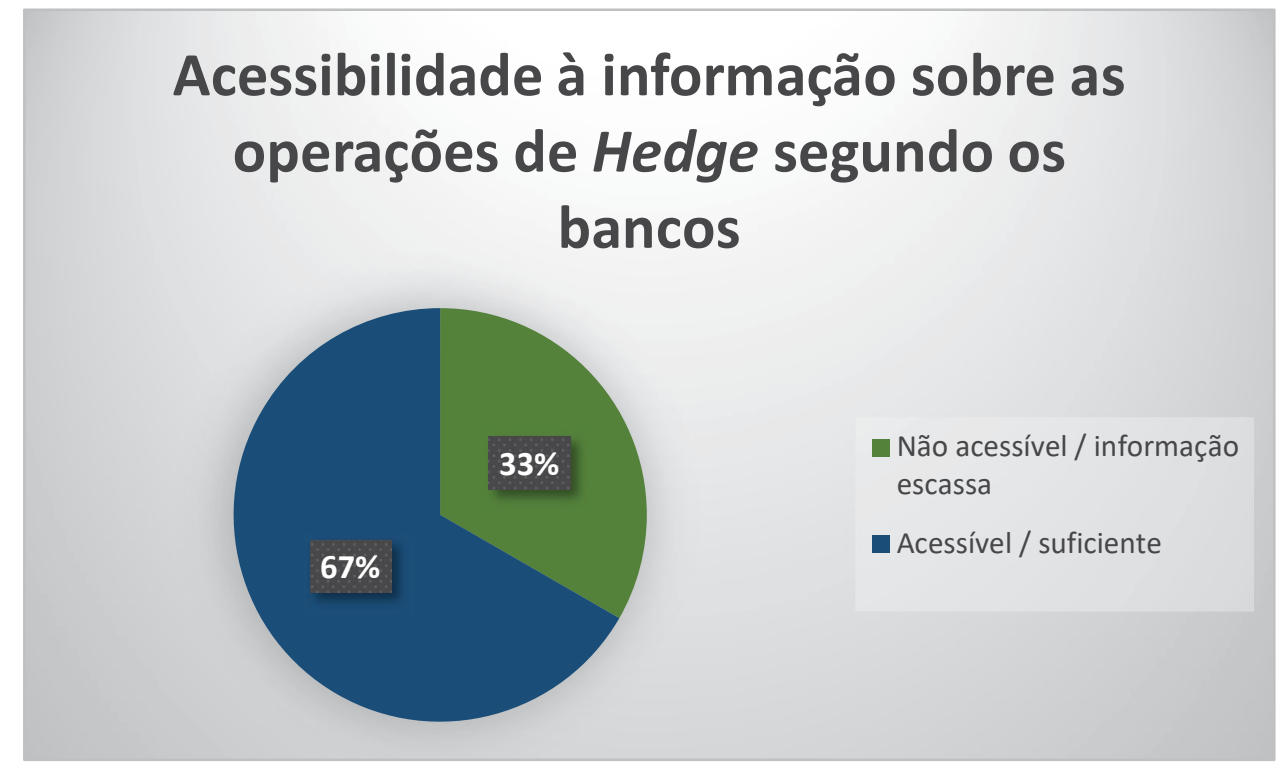

Fonte: Elaborado pelo autor

\subsection{AS PRINCIPAIS OPERAÇÕES UTILIZADAS}

As operações de hedge utilizadas pelos micros e pequenos empresários encontrados nesta amostra de dados são, em sua maioria, do mercado de câmbio. O pagamento antecipado é uma das operações mais usadas em especial pelos importadores. Além disso, foram citadas as travas de câmbio, o adiantamento sobre contrato de câmbio (ACC) e por último o fundo cambial, que é um produto bancário.

A tabela 7 demostra a relação das operações utilizadas pelos empresários e as operações de hedge mais demandadas nos bancos comerciais. As travas de câmbio é a única operação entre as mais demandadas nos bancos que os bancos comerciais entrevistados oferecem. Além disso, há demanda por ACEs por parte dos exportadores e no mercado de derivativos os mais demandados são os $N D F s$ e os Swaps. Já as opções flexíveis não são tão demandas pelos micros e pequenos empresários, pois, segundo os bancos, possuem uma alta complexidade. 
Tabela 7 - As operações de hedge utilizadas pelos empresários e as operações de hedge demandadas nos bancos

\begin{tabular}{|c|c|c|c|}
\hline \multicolumn{4}{|c|}{ AS OPERAÇÕES DE HEDGE UTILIZADAS PELOS EMPRESÁRIOS } \\
\hline $\begin{array}{l}\text { Pagamento } \\
\text { antecipado }\end{array}$ & Fundo cambial & Trava de Câmb & $(\mathrm{ACC})$ \\
\hline \multicolumn{4}{|c|}{ AS OPERAÇÕES DE HEDGE DEMANDADAS NOS BANCOS } \\
\hline $\begin{array}{c}\text { Trava de Câmbio } \\
\text { (ACC) }\end{array}$ & $\begin{array}{c}\text { Adiantamento de Contrato de } \\
\text { Exportação (ACE) }\end{array}$ & $\begin{array}{l}\text { NDF (Termo de } \\
\text { moeda) }\end{array}$ & $\begin{array}{c}\text { Contratos } \\
\text { SWAP }\end{array}$ \\
\hline
\end{tabular}

Fonte: Elaborado pelo Autor

As instituições financeiras citaram, durante as entrevistas, algumas operações que são voltadas aos exportadores como o adiantamento sobre contrato de câmbio (ACC) e o adiantamento sobre cambiais entregues (ACE). O ACC é um financiamento à exportação que pode ser efetuado antes do embarque da mercadoria ou até para produzi-la, ou seja, o contrato de câmbio é celebrado antes do exportador receber o pagamento do comprador. O ACE é um mecanismo similar ao ACC, contratado após o embarque dos produtos, tratasse de um tipo de financiamento, pois o exportador recebe os recursos de sua exportação adiantados, podendo conceder um prazo de pagamento maior para o comprador. (ATSUMI, 2009).

\subsection{AS OPERAÇÕES DE HEDGE (DERIVATIVOS) NA BOLSA DE VALORES}

As operações de hedge em derivativos na bolsa de valores foram consideradas somente por 1/3 dos empresários da amostra desta pesquisa. Os outros empresários entrevistados nunca consideraram ou procuraram se informar desta possibilidade. Entretanto, os bancos consideram a proteção direta na bolsa de valores como uma opção, mas alertam que elas só são vantajosas para valores maiores e que geralmente os vencimentos das operações não são as mesmas que as operações de importação e exportação.

Conforme a tabela 8 , as principais vantagens segundo os bancos entrevistados são a liquidez, que permite a saída do contrato antes do vencimento e o preço mais acessível que o mercado de balcão. Entretanto os valores fixos de contrato e vencimentos fixos são as principais desvantagens. Ainda foi afirmado pelos entrevistados que a necessidade de margem e o ajuste diário, que é necessário nas operações em bolsa, muitas vezes é impeditivo para os empresários. Por fim, um dos entrevistados afirmou que só seria viável proteger-se na bolsa para operações maiores e perene, pois sempre haverá diferenças de montantes e prazos, o que torna este tipo de operação complexa para o micro e pequeno empresário. 
Tabela 8 - Operações de hedge na bolsa de valores: vantagens e desvantagens

\begin{tabular}{|l|l|}
\hline \multicolumn{2}{|c|}{ Operações de hedge na bolsa de valores } \\
\hline Vantagens & Desvantagens \\
\hline $\begin{array}{l}\text { Liquidez, capacidade de sair do contrato antes do } \\
\text { vencimento }\end{array}$ & Valores fixos de contrato \\
\hline Preço melhor que o de balção (Spread menor) & $\begin{array}{l}\text { Vencimentos com datas } \\
\text { fixas }\end{array}$ \\
\hline & Necessidade de margem \\
\hline & Ajuste diário \\
\hline
\end{tabular}

Fonte: Elaborado pelo autor

\subsection{AS DIFICULDADES DOS MICROS E PEQUENOS EMPRESÁRIOS}

As dificuldades dos micros e pequenos empresários em realizar as operações de proteção cambial estão em sua maioria relacionadas aos custos ou a percepção do valor da operação. As MPEs em geral acreditam que o custo da operação não compensa o benefício e consideram a operação como um custo extra em sua importação ou exportação.

Foi destacada a falta de conhecimento necessário pelos funcionários dos bancos para efetuar a oferta dos mecanismos mais adequados para as suas necessidades. Além disso, os empresários consideram a impossibilidade de liquidar os contratos de trava de câmbio ao banco antecipadamente, quando o câmbio está favorável, uma desvantagem. Por fim, as operações em bolsa são consideradas, em geral, como muito burocráticas e complexas pelos empresários.

A falta de conhecimento das operações pelos empresários é mencionada pelos bancos como principal dificuldade para a realização das mesmas pelas MPEs. Segundo eles, não há uma percepção dos empresários da vantagem em realizar proteção cambial, pois muitos consideram a operação um custo adicional e preferem ficar desprotegidos.

Segundo os bancos, o custo da operação em comparação ao risco do ajuste para operações mais elevadas também é muitas vezes impeditivo. Estas operações que possuem ajustes, como o $N D F$, podem ser percebidas como um risco para o caixa da empresa, pois o ajuste pode ser elevado nominalmente se a variação for muito elevada, o que requere um planejamento mais profundo ao utilizar a operação.

Por fim, a necessidade de um limite de crédito elevado para realizar as operações é apontado pelos bancos como uma dificuldade para viabilizar este tipo de operação para as micros e pequenas empresas. Entretanto foi mencionado que o limite afeta mais as 
microempresas do que as pequenas empresas, pois as primeiras, em geral, não possuem limite elevado para suportar diversas operações ao mesmo tempo.

A tabela 9 demonstra as principais dificuldades apontadas por bancos e empresários para realizar as operações de hedge. É possível observar que muitas destas dificuldades estão relacionadas com os custos das operações e a falta de conhecimento técnico das operações que dificultam a percepção da vantagem de utilizar estas operações para proteger-se da variação cambial.

Tabela 9 - As principais dificuldades dos empresários para utilizar operações de hedge

\section{As principais dificuldades dos empresários para utilizar operações de hedge}

\begin{tabular}{|l|l|}
\hline Segundo os próprios empresários & Segundo os bancos \\
\hline Custo da operação & Falta de conhecimento \\
\hline Excesso de burocracia (nas operações de bolsa) & $\begin{array}{l}\text { Custo da operação vs Risco para o } \\
\text { fluxo de caixa }\end{array}$ \\
\hline $\begin{array}{l}\text { Falta de oferta dos mecanismos adequados pelos } \\
\text { bancos }\end{array}$ & Limite de crédito \\
\hline $\begin{array}{l}\text { Não há possibilidade de antecipar o contrato quando } \\
\text { o câmbio está favorável }\end{array}$ & $\begin{array}{l}\text { Percepção do custo da operação } \\
\text { pelo empresário }\end{array}$ \\
\hline & $\begin{array}{l}\text { Falta de conhecimento dos } \\
\text { funcionários do banco }\end{array}$ \\
\hline
\end{tabular}

Fonte: Elaborado pelo autor 


\section{CONCLUSÃO}

Esta sessão do projeto aplicado se dispõe em analisar os dados apresentados na seção resultados de pesquisa e, com base nestes resultados, indicar as considerações finais. Para realizar esta analise a estrutura de apresentação desenvolvida na sessão anterior será parcialmente mantida, sendo os resultados analisados na ordem exposta na seção resultados.

Ao analisar a amostra dos entrevistados este estudo sugere que os importadores tendem a dar maior relevância para os mecanismos cambiais que os exportadores. Este resultado conforma a percepção do mercado de que os importadores demandam mais os mecanismos de proteção cambial, por possuírem o seu fluxo de caixa atrelado às variações cambiais. $\mathrm{Na}$ hipótese inicial, já se imaginava que os importadores teriam um maior conhecimento sobre o assunto, o que se confirmou nas respostas das instituições bancárias aos questionários.

Evidenciasse que os micros e pequenos empresários tem conhecimento limitado sobre as operações ou não o possuem. Fato que é comprovado pelos resultados obtidos nos questionamentos feitos aos empresários sobre seu nível de conhecimento dos mecanismos disponíveis e pela percepção dos representantes das instituições bancárias deste conhecimento.

A maioria dos empresários entrevistados não consegue diferenciar as operações de balcão das operações do mercado de câmbio, o que demonstra um conhecimento reduzido das diferenças entre as operações de proteção cambial. O estudo sugere ainda que as informações sobre proteção cambial são escassas, porém a maioria dos analistas das instituições bancárias questionados acredita que as informações são suficientes, o que demostra um conflito de perspectiva de ambos os lados.

As instituições financeiras acreditam que estão divulgando e oferecendo corretamente as operações de hedge, entretanto para alguns dos questionados nunca foi oferecido este tipo de operação. Além disso, foi citado pelos empresários que os bancos não se encontram suficientemente preparados para oferecer as operações que são mais vantajosas para os seus negócios, evidenciando uma falta de preparo dos funcionários destas instituições para atender a esse tipo de cliente. O estudo revelou que muitos dos funcionários, na visão dos empresários, não conhecem as operações disponíveis e por consequência não possuem condições de ofertalas aos clientes, fato que também é confirmado pelos representantes das instituições bancárias. Considerando que os pequenos empresários geralmente são atendidos pelos funcionários que, em sua maioria, não são de alto-escalão, o resultado aqui obtido preocupa, pois estes empresários no geral possuem conhecimentos superficiais sobre as operações e, portanto, é 
necessário que a proposta e a exposição destas operações sejam feitas pelos bancos de forma mais incisiva.

As operações mais utilizadas pelos empresários e demandadas pelos bancos não coincidiram, o que pode ter sido causado pela análise de amostra limitada. As operações utilizadas pelos empresários na sua maioria são operações do mercado de câmbio, como pagamento antecipado e operações de ACC. Somente um dos questionados afirmou utilizar um fundo cambial, que indiretamente utiliza operações de balcão e de bolsa, pois é atrelado a flutuação de uma moeda estrangeira e derivativos. Os bancos por sua vez mencionaram que o $N D F$ é um dos produtos mais demandados, porém em nenhum momento os empresários questionados neste estudo mencionaram que utilizam esta modalidade, somente que a conhecem.

A única operação mencionada por ambos os lados foi a trava de câmbio por meio de uma operação de ACC que é uma operação cambial baseada em adiantamento de recebíveis ou no ato de fixar a taxa de câmbio de uma operação a pagar, ou seja, é um tipo de financiamento. (ATSUMI, 2009). Neste sentido, os empresários e os funcionários dos bancos afirmaram que a preferência por este tipo de operação se deve ao fato de ele ser interessante para o controle do fluxo de caixa da empresa, que nas micros e pequenas empresas é limitado. Além disso, conforme os entrevistados, a burocracia e custo das operações é considerada um custo adicional que muitos dos empresários não estão dispostos a despender, o que acarreta a não contratação deste tipo de operação pelos empresários, que preferem em sua maioria operações mais simples.

Este estudo sugere que somente uma pequena parcela, de 33\% dos empresários entrevistados, considerou a utilização da bolsa de valores como opção de hedge, pois para a maioria deles é um processo muito burocrático e complexo. Por sua vez, os bancos consideram as operações em bolsa como uma alternativa, mas não a recomendam para pequenos empresários, pois a falta de fluxo de caixa e os contratos fechados podem vir a afetar a estabilidade dos negócios.

Entretanto, o estudo efetuado sugere que os custos dos contratos em bolsa frente aos custos cobrados pelos bancos é um diferencial a favor das operações em bolsa. Estes contratos possuem maior liquidez, o que é considerado uma necessidade para os pequenos empresários, portanto podem ser uma alternativa interessante aos empresários que possuem recursos suficientes para cobrir a margem e os ajustes diários, desde que bem estudados. (BANCO DO BRASIL, 2018). Por outro lado, este estudo apontou uma tendência de maior familiaridade dos 
empresários com NDFs e, portanto, estas operações são as recomendadas para aqueles empresários que não possuem o conhecimento necessário ou não desejam dedicar tempo para o estudo de operações mais complexas.

Por fim, a principal dificuldade exposta pelos empresários e analistas de bancos foi a falta de conhecimento das operações e a percepção da operação de hedge como um custo adicional. Segundo os entrevistados do setor bancário, o pequeno empresário tem dificuldade de enxergar o "valor" da operação de proteção e acredita que ela irá aumentar seu custo, preferindo, muitas vezes, correr o risco da variação cambial, o que pode acarretar prejuízos futuros. Esta percepção de valor se relaciona diretamente a falta de acesso às informações e ao conhecimento limitado sobre as operações que tanto micros empresários e alguns funcionários de bancos possuem.

O estudo efetuado demostra que, em ambos os lados, há falta de acesso às informações sobre as operações. Considerando que as informações relevantes para a tomada de decisão dos empresários não estão sendo suficientes, o estudo também recomenda o aumento da capacitação dos funcionários das instituições financeiras no que tange as operações de proteção cambial, e uma maior exposição e discussão com micro e pequenos empresários sobre as operações, através de cursos ou palestras. Outro ponto relevante apontado pelo estudo a ser considerado pelos bancos, é a flexibilização das operações para melhor atender o micro e pequeno empresário, visto que, uma das maiores dificuldades mencionadas é a impossibilidade de liquidar o contrato antecipadamente.

Este trabalho objetivou a investigação dos mecanismos disponíveis de proteção cambial para MPEs brasileiras o que foi realizado através da pesquisa do referencial teórico e do questionamento a respeito das operações realizadas pelos micros e pequenos empreendedores. Através da aplicação do questionário semiestruturado, foi possível chegar à conclusão que os micros e pequenos empresários, em sua maioria, tem conhecimento limitado sobre os mecanismos disponíveis e as principais vantagens da proteção cambial, pois veem este tipo de operação como um custo.

Outrossim, foi verificado que o acesso dos micros e pequenos empresários às informações pertinentes sobre as operações é limitado e necessita ser melhorado. A falta de acesso advém de um déficit de conhecimento dos funcionários dos bancos sobre as operações que acarreta na impossibilidade de oferece-las, da divulgação escassa destas operações e da falta de interesse do micro e pequeno empresário. Por fim, o estudo propôs a análise da 
viabilidade de proteção cambial com custo reduzido e envolvendo pequenos valores. Esta análise foi realizada através da pesquisa a respeito das operações e dos questionários aos bancos e empresários que demostrou que é possível realizar as operações. Entretanto, os questionários revelaram uma preferência por operações mais simples e geralmente atreladas ao mercado cambial. Considerando que o custo das operações é reduzido, o estudo sugere que a utilização de mecanismos de hedge por micros e pequenos empresários é possível, entretanto ainda é necessário efetuar uma maior divulgação das vantagens da operação junto ao empresariado.

\subsection{LIMITAÇÕES DO ESTUDO}

O estudo realizado apresentou limitações sobre a viabilidade de análise da população como um todo, pois foi utilizada apenas uma amostra. A utilização de amostra prevê o uso de generalizações, o que impossibilita o estudo do tema como um todo, sendo possível resultados diversos em amostras diversas.

A análise das operações de hedge não pretende ser completa, pois foram analisados somente as operações mais comuns dos mercados de câmbio, bolsa de valores e mercado de balcão. A análise extensa não atenderia os objetivos deste projeto aplicado que pretende somente analisar um tipo de mecanismo específico. Além disso, novos mecanismos mais apropriados aos objetivos deste trabalho podem surgir a qualquer momento ou podem não ter sido analisados, pois não foram considerados relevante no momento de esquematização deste projeto aplicado.

\subsection{SUGESTÕES PARA FUTURAS PESQUISAS}

Este projeto aplicado teve como objetivo analisar a viabilidade da utilização de mecanismos de hedge por micro e pequenos empresários, entretanto durante o seu desenvolvimento alguns pontos relevantes para o estudo do tema da proteção cambial foram postos em evidência. Pela limitação temporal e de maneira a não desviar o foco deste projeto aplicado, estes temas não foram abordados neste trabalho.

Considerando que a falta de conhecimento é um dos principais pontos abordados neste projeto aplicado, uma pesquisa sobre o marketing dos mecanismos de hedge e do treinamento dos funcionários das instituições bancárias seriam uma excelente contribuição sobre o tema. Consequentemente, um estudo sobre a educação financeira dos empresários e da divulgação das operações de câmbio seria relevante. 


\section{REFERÊNCIAS}

ALMEIDA, Luciana Florêncio De; MACHADO FILHO, Cláudio Antonio Pinheiro. Sharing competences in strategic: alliances: a case study of the Cosan and Shell biofuel venture. Revista de Administração, [s. 1.], v. 48, p. 359-374, 2013. Disponível em: http://www.rausp.usp.br/busca/artigo.asp?num artigo=1518

ANG, Andrew; GOROVYY, Sergiy; VAN INWEGEN, Gregory B. Hedge fund leverage. Journal of Financial Economics, [s. 1.], v. 102, n. 1, p. 102-126, 2011. Disponível em: http://dx.doi.org/10.1016/j.jfineco.2011.02.020

ARDANT, Henri. Introduction a l'Étude des Banques et des Opérations de Banque. Paris: Dunod, 1954.

ASSAF NETO, Alexandre. Mercado Financeiro. 9ed. ed. São Paulo: Atlas, 2010.

ASSAF NETO, Alexandre. Mercado Financeiro: Exercícios e Prática. Ribeirão Preto, SP, Brasil: Inside Books Editora, 2009.

ATSUMI, Shirley Yurica Kanamori. Negócios Financeiros Internacionais. Curitiba, PR: IESDE Brasil, 2009.

B3: A BOLSA DO BRASIL. Mini Opções sobre Taxa de Câmbio de Reais por Dólar Comercial - Vencimentos Semanais. 2020. Disponível em: $<$ http://www.b3.com.br/pt_br/produtos-e-servicos/negociacao/moedas/mini-opcoes-sobretaxa-de-cambio-de-reais-por-dolar-comercial-vencimentos-semanais.htm>. Acesso em: 20 mar. 2020.

B3: A BOLSA DO BRASIL. Swap. 2020. Disponível em: $<$ http://www.bmfbovespa.com.br/pt_br/produtos/mercado-de-balcao/derivativos/swap.htm>. Acesso em: 15 mar. 2020.

BANCO BRADESCO. Trava de câmbio. [s.d.]. Disponível em: $<$ https://banco.bradesco/html/pessoajuridica/solucoes-integradas/comercioexterior/exportacao/trava-cambio.shtm>. Acesso em: 6 jun. 2019.

BANCO CENTRAL DO BRASIL. 25 anos do Real. [s.d.]. Disponível em: $<$ https://www.bcb.gov.br/controleinflacao/25anosreal>. Acesso em: 25 out. 2019.

BANCO DO BRASIL. Proteção Financeira. [s.1.] : Universidade Corporativa Banco do Brasil, 2018.

BANCO MUNDIAL. Banco de dados: Brazil, 2020. Disponível em: https://data.worldbank.org/country/brazil?locale $=\mathrm{pt}$

BANK OF ENGLAND. Preparing for 2022: What you need to know about LIBOR transition. 2018.2 Disponível em: $<$ https://www.google.com.br/url?sa=t\&rct=j\&q=\&esrc=s\&source=web\&cd=\&cad=rja\&uact $=$ $8 \&$ ved=2ahUKEwi43I-

t5J3qAhWCG7kGHeeADxEQFjABegQIDBAD\&url=https\%3A\%2F\%2Fwww.bankofenglan d.co.uk $\% 2$ F- $\% 2$ Fmedia $\% 2$ Fboe $\% 2$ Ffiles $\% 2$ Fmarkets $\% 2$ Fbenchmarks $\% 2$ Fwhat-you-need-toknow-about-lib>. Acesso em: 25 jun. 2020.

BAPTISTA, Luiz Olavo. Contratos Internacionais. São Paulo: Lex Editora, 2010. 
BESSADA, Octavio; BARBEDO, Claudio; ARAÚJO, Gustavo. Mercado de Derivativos no Brasil. $4^{\mathrm{a}}$ ed. ed. Rio de Janeiro: Record, 2012.

BIDERMAN, Maria Tereza Camargo. Dicionário de Termos Financeiros e Bancários. Edição 1 ed. [s.1.] : Disal Editora, 2019.

BORDIM, Jonas et al. MERCADO CAMBIAL BRASILEIRO. Revista Eletrônica de Iniciação Ciêntifica dos Cursos de Administração e de Ciências Contábeis das Faculdades Integradas Machado de Assis, [s. 1.], p. 1-9, 2010. Disponível em: http://www.fema.com.br/site/wp-content/uploads/2016/09/9-Mercado-Cambial-Brasileiro.pdf

BORGES, Joni Tadeu. Financiamento ao comércio exterior. [s.1.] : Intersaberes, 2012.

BRANSKI, Regina Meyer; FRANCO, Raul A.; LIMA JÚNIOR, Orlando. METODOLOGIA DE ESTUDO DE CASOS APLICADA À LOGÍSTICA. In: XXIV ANPET CONGRESSO DE PESQUISA E ENSINO EM TRANSPORTE 2011, Salvador. Anais... Salvador

BRASIL, Ministério da indústria comércio exterior e serviços. Importação. [s.d.]. Disponível em: <http://www.mdic.gov.br/index.php/comercio-exterior/importacao>. Acesso em: 29 ago. 2019.

BRASIL, Receita Federal Do. INSTRUÇÃO NORMATIVA RFB No 1801 , DE 26 DE MARÇO DE 2018. . 2018. HIGACHI, Hermes Yukio et al. Crescimento, ciclo econômico, mudança tecnológica e financiamento. Economia e Sociedade, [s. 1.], v. 25, n. 3, p. 533-568, 2016. Disponível em: http://www.scielo.br/scielo.php?script=sci arttext\&pid=S0104$\underline{06182016000300533 \& \operatorname{lng}=p t \& t \operatorname{lng}=\mathrm{pt}}$

BROWN, Gregory W. Managing Foreign Exchange Risk with Derivatives. Journal of Financial Economics, [s. 1.], v. 60, n. 2-3, p. 401-448, 2001.

BRUNI, Adriano Leal. Avaliação de Investimentos. São Paulo: Atlas, 2008.

BTG PACTUAL. Fundos Cambiais. 2020. Disponível em: $<$ https://www.btgpactualdigital.com/fundos-de-investimento/fundos-cambiais $>$. Acesso em: 19 jun. 2020.

CALDEIRA, João Frois et al. Seleção de carteiras com modelos fatoriais heterocedásticos: aplicação para fundos de fundos multimercados. RAM. Revista de Administração Mackenzie, [s. 1.], v. 15, n. 2, p. 127-161, 2014. Disponível em: http://apps.webofknowledge.com/full_record.do?product=UA\&search_mode=GeneralSearch

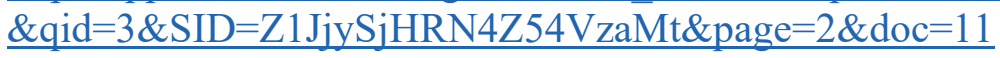

CAMARGO, Patrícia Olga. A evolução recente do setor bancário no Brasil. São Paulo: Cultura Acadêmica, 2009. Disponível em: $<$ https://pdfdocumento.com/a-evoluao-recente-dosetor-bancario-no-brasil-scielo-livros_59f55de11723dd0567196ba6.html>

CARNEIRO, Flávio Lyrio. A INFLUÊNCIA DA TAXA DE CÂMBIO SOBRE OS FLUXOS DE COMÉRCIO EXTERIOR. Repositório do Conhecimento do Ipea, [s. 1.], 2014.

CONSELHO MONETÁRIO NACIONAL DO BRASIL. Instrução Normativa RFB n 1801, de 26 de março de 2018. 2018. Disponível em: $<$ http://normas.receita.fazenda.gov.br/sijut2 consulta/link.action?visao=anotado\&idAto $=90994$ $>$. Acesso em: 25 jul. 2019.

CORRETORA DE INVESTIMENTOS, XP. Fundos cambiais: entenda o que são e veja como aplicar nesse investimento. 2020. Disponível em: 
$<$ https://conteudos.xpi.com.br/aprenda-a-investir/relatorios/fundos-cambiais/>. Acesso em: 10 out. 2019.

CORRETORA DE VALORES, Rico. Mercado de Opções: O que é, Vantagens e Como Investir. 2018. Disponível em: <https://blog.rico.com.vc/mercado-de-opcoes $>$. Acesso em: 2 abr. 2020.

CRESWELL, John W. Projeto de pesquisa: métodos qualitativo, quantitativo e misto. 3 ed. ed. Porto Alegre: Artmed, 2010.

FIGUEIREDO, Antonio Carlos. Introdução aos Derivativos. São Paulo: Pioneira Thomson Learning, 2017.

FLICK, Uwe. Introdução à metodologia de pesquisa: um guia para iniciantes. Porto Alegre: Penso, 2013. Disponível em: https://www.ets.ufpb.br/pdf/2013/2 Metodos quantitat e qualitat IFES/Bauman, Bourdieu, Elias/Livros de Metodologia/Flick - Introducao à Metodologia da Pesquisa.pdf

FONSECA, José Wladimir Freitas Da. Mercado de Capitais. Curitiba: IESDE Brasil, 2009.

FORBES, Luiz F. Mercados Futuros: Uma introdução. São Paulo: Bolsa de Mercadorias \& Futuros, 1994.

FORTUNA, Eduardo. Mercado financeiro: produtos e serviços. 19. ed. re ed. Rio de Janeiro: Qualitymark Editora, 2013.

GIL, Antonio Carlos. Como elaborar projetos de pesquisa. 4.ED ed. São Paulo: Atlas, 2008. GIRARDI, Altair. Os impactos da variação cambial nos resultados das empresas avícolas e as ferramentas de hedge para minimizá-los. 2016. Universidade Tecnológica Federal do Paraná, [s. 1.], 2016.

HULL, John C. University of Toronto. Introdução aos mercados de futuros e de opções. 2 nd. ed. São Paulo: Cultura Editores Associados, 1996.

HULL, John C. University of Toronto. Introduction to Future and Options Markets. 3rd. ed. New Jersey, United States of America: Prentice-Hall Inc., 1997.

HULL, John C. University of Toronto. Options, Futures, \& Other Derivatives. 4ed. ed. New Jersey, United States of America: Prentice-Hall Inc., 2000.

INTERNACIONAL, Fundo Monetário. International Capital Markets: Developments, Prospects, and Key Policy Issues. Washington: International Monetary Fund, 1999.

JIANG, Wei; LI, Kai; WANG, Wei. Hedge Funds and Chapter 11. The Journal of Finance, [s. 1.], v. 67, n. 2, p. 513-560, 2012. Disponível em: http://dx.doi.org/10.1111/j.15406261.2012.01724.X\%5Cnhttp://doi.wiley.com/10.1111/j.1540-6261.2012.01724.X

LESSARD, Donald; SERCU, Piet; UPPAL, Raman. International Financial Markets and the Firm. Cincinnati, Ohio. United States of America: South-Western College Publishing, 2006. v. 51.

LEVI, Maurice D. (University of British Columbia). International Finance: The markets and financial management of multinational business. 2nd. ed. New York: McGraw-Hill, Inc, 1990. 
LOPES, João Luiz Guillaumon; SCHIOZER, Rafael Felipe; SHENG, Hsia Hua. Hedge e especulação com derivativos cambiais: evidências de operações cotidianas. Revista de Administração Contemporânea, [s. 1.], v. 17, n. 4, p. 438-458, 2013.

MACEDO CINTRA, Antonio Marcos; COSTA PINTO, Eduardo. China em transformação : transição e estratégias de desenvolvimento. Revista de Economia Política, [s. 1.], v. 37, n. 147, p. 381-400, 2017.

MANZINI, Eduardo José. Entrevista semi-estruturada: análise de objetivos e de roteiros. In: SEMINÁRIO INTERNACIONAL SOBRE PESQUISA E ESTUDOS QUALITATIVOS 2004, Bauru. Anais... Bauru: USC, 2004.

MATTAR, F. .. Pesquisa de marketing. São Paulo: Atlas, 2001.

MINISTÉRIO DA ECONOMIA DO BRASIL. Estatísticas de Comércio Exterior. 2020. Disponível em: $\quad<$ http://www.mdic.gov.br/comercio-exterior/estatisticas-de-comercioexterior/>. Acesso em: 20 ago. 2019.

MOLLER, Lucas. Alternativas De Proteção Cambial Para Empresas Exportadoras Brasileiras E O Uso De Opções. 2017. Universidade Federal do Rio Grande do Sul, [s. 1.], 2017.

PARACHE, Varela. La Actual Crisis Financiera y Los Hedge Funds. Revista de Economía Mundial, [s. 1.], v. 18, 2008.

RATTI, Bruno. Comércio Internacional e Câmbio. 9ed. ed. São Paulo: Aduaneiras, 1997.

RAYÓN, Elitania Leyva. Hedge funds y riesgo sistémico : análisis de la probabilidad de quiebra de los fondos de inversión libre. Research Gate, [s. 1.], v. XXIV, p. 31-58, 2009.

RECEITA FEDERAL DO BRASIL. Mercado financeiro (imposto sobre a renda auferida nos mercados financeiro e de capitais). 2019. Disponível em: $<$ http://receita.economia.gov.br/acesso-rapido/legislacao/legislacao-por-assunto/ir-mercadofinanceiro>. Acesso em: 19 jun. 2020.

ROSSI, Pedro. Taxa de câmbio e política cambial no Brasil: teoria, institucionalidade, papel da arbitragem e da especulação. Edição 1 ed. São Paulo: Editora FGV, 2016.

SANGUANINI, José Luiz; FACCIN, Kadígia. Derivativos: Uma abordagem a cerca da visão de hedge cambial por uma empresa de pequeno porte. Global Manager, [s. 1.], v. 12, n. 1, p. 112-130, 2012.

SANTOS, Mariana Szilagyi. O fluxo de caixa aplicado à micro e pequena empresa. Repositório Institucional da Universidade Federal de Rondônia, [s. 1.], 2010.

SEBRAE. Confira as diferenças entre micro empresa, pequena empresa e MEI. [s.d.]. Disponível em: < https://www.sebrae.com.br/sites/PortalSebrae/artigos/entenda-as-diferencasentre-microempresa-pequena-empresa-e-

mei,03f5438af1 c92410VgnVCM100000b272010aRCRD>. Acesso em: 19 jun. 2020.

SIQUEIRA, Geraldo Magela. Câmbio e Capitais Internacionais: O Relacionamento Financeiro do Brasil com o Exterior. Porto Alegre: Aduaneiras, 2016.

SOLNIK, Bruno. International Investiments. $3^{\mathrm{a}}$ ed ed. [s.1.] : Addison-Wesley Publishing Company, Inc., 1996. 
SOUZA, Luís Fabiano De. Análise De Instrumentos De Hedge Utilizados No Mercado Cambial: Um Estudo Com Base Nas Práticas Do Banco Santander. 2008. Universidade Federal do Rio Grande do Sul, [s. 1.], 2008. Disponível em: https://www.lume.ufrgs.br/bitstream/handle/10183/18076/000653086.pdf?sequence=1

TORRES FILHO, Ernani Teixeira; POSE, Mirko. a Internacionalização Da Moeda Chinesa: Disputa Hegemônica Ou Estratégia Defensiva? Revista de Economia Contemporânea, [s. 1.], v. 22, n. 1, p. 1-23, 2018.

VARGA, Gyorgy; WENGERT, Maxim. A indústria de fundos de investimentos no Brasil. Revista de Economia e Administração, [s. 1.], v. 10, n. 1, p. 66-109, 2011.

VAZQUEZ, José Lopes. Comércio Exterior Brasileiro. 5ed. ed. São Paulo: Atlas, 2001.

VIERA, Aquiles. Teoria e Prática Cambial: exportação e importação. Porto Alegre: Aduaneiras, 2015.

WENG, Haijie; TRÜCK, Stefan. Style analysis and Value-at-Risk of Asia-focused hedge funds. Pacific Basin Finance Journal, [s. 1.], v. 19, n. 5, p. 491-510, 2011. Disponível em: http://dx.doi.org/10.1016/j.pacfin.2011.05.002

WHITMAN, Martin J.; DIZ, Fernando. Distress Investing. New Jersey, United States of America: John Wiley \& Sons, Inc., 2009.

WORLD TRADE ORGANIZATION. WORLD TRADE STATISTICAL REVIEW 2018. [s.l: s.n.]. Disponível em: <www.wto.org/statistics>.

YIN, Robert K. Estudo de Caso: planejamento e métodos. 5.ED ed. Porto Alegre: Bookman, 2015.

ZINI JÚNIOR, Álvaro Antônio. Taxa de Câmbio e Política Cambial no Brasil. São Paulo: Editora da Universidade de São Paulo, 1995. 


\section{APÊNDICE}

\section{Apêndice 1 - Simulação de opção de venda de dólar (opção exercida)}

\begin{tabular}{|c|c|c|}
\hline & opção de venda (Exportação) & \\
\hline Quantidades de lotes & & 5 \\
\hline Valor do contrato (principal) & $\$$ & $250.000,00$ \\
\hline Taxa de câmbio acordada & $\mathrm{R} \$$ & 4,50 \\
\hline Prêmio Pago & $-R \$$ & $25.000,00$ \\
\hline Valor do contrato no vencimento & $\mathrm{RS}$ & $1.125 .000,00$ \\
\hline Taxa de câmbio PTAX no vencimento & $\mathrm{RS}$ & 3,00 \\
\hline Valor câmbio PTAX & $\mathrm{RS}$ & $750.000,00$ \\
\hline Ajuste & $\mathrm{R} \$$ & $375.000,00$ \\
\hline imposto de renda (15\%) & $-R S$ & $56.250,00$ \\
\hline valor total do câmbio & $\mathrm{RS}$ & $1.043 .750,00$ \\
\hline taxa de câmbio efetiva & $\mathrm{RS}$ & 4,18 \\
\hline Exerce a opção? & Sim, pois a cotação efetiva é $m$ & \\
\hline
\end{tabular}

Fonte: Elaborado pelo autor.

Apêndice 2 - Simulação de opção de venda de dólar (opção não exercida)

\begin{tabular}{|c|c|}
\hline & Opção de venda (Exportação) \\
\hline Quantidades de lotes & 5 \\
\hline Valor do contrato (principal) & $250.000,00$ \\
\hline Taxa de câmbio acordada & 4,50 \\
\hline Prêmio Pago & $25.000,00$ \\
\hline Valor do contrato no vencimento & $1.125 .000,00$ \\
\hline Taxa de câmbio PTAX no vencimento & 5,00 \\
\hline Valor câmbio PTAX & $1.250 .000,00$ \\
\hline Ajuste & $125.000,00$ \\
\hline imposto de renda (15\%) & $\mathrm{R} \$$ \\
\hline valor total do câmbio & $975.000,00$ \\
\hline taxa de câmbio efetiva & 3,90 \\
\hline Exerce a opção? & Não, pois o câmbio efetivo é menor que o câmbio PTAX. Se perde o valor do prêmio. \\
\hline Valor do câmbio sem exercer a opção & $1.225 .000,00$ \\
\hline Taxa efetiva sem exercer opção & 4,90 \\
\hline
\end{tabular}

Fonte: Elaborado pelo autor. 
Apêndice 3 - Questionário aplicado às instituições financeiras

1) Considerando a sua experiência no setor bancário, você considera que os empresários brasileiros possuem conhecimento das opções de operações financeiras para proteção cambial? O maior conhecimento é demonstrado pelos empresários que trabalham com exportação ou importação?

2) Considera que a divulgação das operações disponíveis de proteção cambial é feita de maneira correta? Caso não, como deveria ser feita esta divulgação?

3) Segundo a sua percepção quais são as dificuldades que os micros e pequenos empresários enfrentam para utilização de operações de proteção cambial de balcão? Há valores mínimos para efetuar as operações? O limite de crédito é um fator relevante? O limite impede as operações?

4) Considerando a sua experiência no setor bancário, o mercado de balcão oferece operações financeiras suficientes para os micros e pequenos empresários que operam importações ou ele é deficitário?

5) Qual é a sua opinião a respeito das operações de proteção cambial na bolsa de valores? Especulação? Proteção cambial?

6) As operações de proteção cambial na bolsa de valores podem, na sua perspectiva, ser uma alternativa para o mercado de balcão? Quais as vantagens e desvantagens destas operações?

7) Segundo a sua vivência, é possível afirmar que as micro e pequenas empresas possuem acesso adequado aos procedimentos de proteção cambial voltados as importações?

8) Considerando a sua vivência bancária e as operações de proteção cambial disponíveis no seu banco, qual é a operação mais demandada pelos empresários? Por que esta operação é mais demanda que as outras? Quais as características que a diferem?

9) Considerando a sua vivência bancária, as ferramentas de proteção cambial disponíveis no mercado de câmbio atendem as necessidades das micro e pequenas empresas?

10) Você gostaria de comentar sobre alguma questão que consideres relevante para a pesquisa e que não foi abordada no questionário anterior? 
Apêndice 4 - Questionário aplicado aos empresários

1) Você trabalha com importação ou exportação ou com os dois?

2) Qual o seu conhecimento sobre proteção cambial?

3) Segundo a sua experiência no dia a dia do comércio exterior, consideras que as informações sobre proteção cambial são acessíveis para micro e pequenas empresas?

4) A sua empresa utiliza algum tipo de proteção cambial nas operações de comércio exterior? Se sim, qual?

5) Você estaria disposto a fixar o câmbio mediante o pagamento de um prêmio para evitar as flutuações cambiais?

6) O Banco com qual a sua empresa trabalha o informou sobre as possibilidades de proteção cambial existentes?

7) A sua empresa já considerou fazer proteção cambial através de operações em bolsa de valores?

8) Você acredita que seja vantajoso efetuar proteção cambial mediante o pagamento de prêmio para não ficar exposto a flutuação do câmbio?

9) Na sua opinião, quais são as maiores dificuldades para a sua empresa efetuar operações de proteção cambial?

10) Gostaria de adicionar algum outro ponto e/ou comentário que consideras relevante para o tema? 

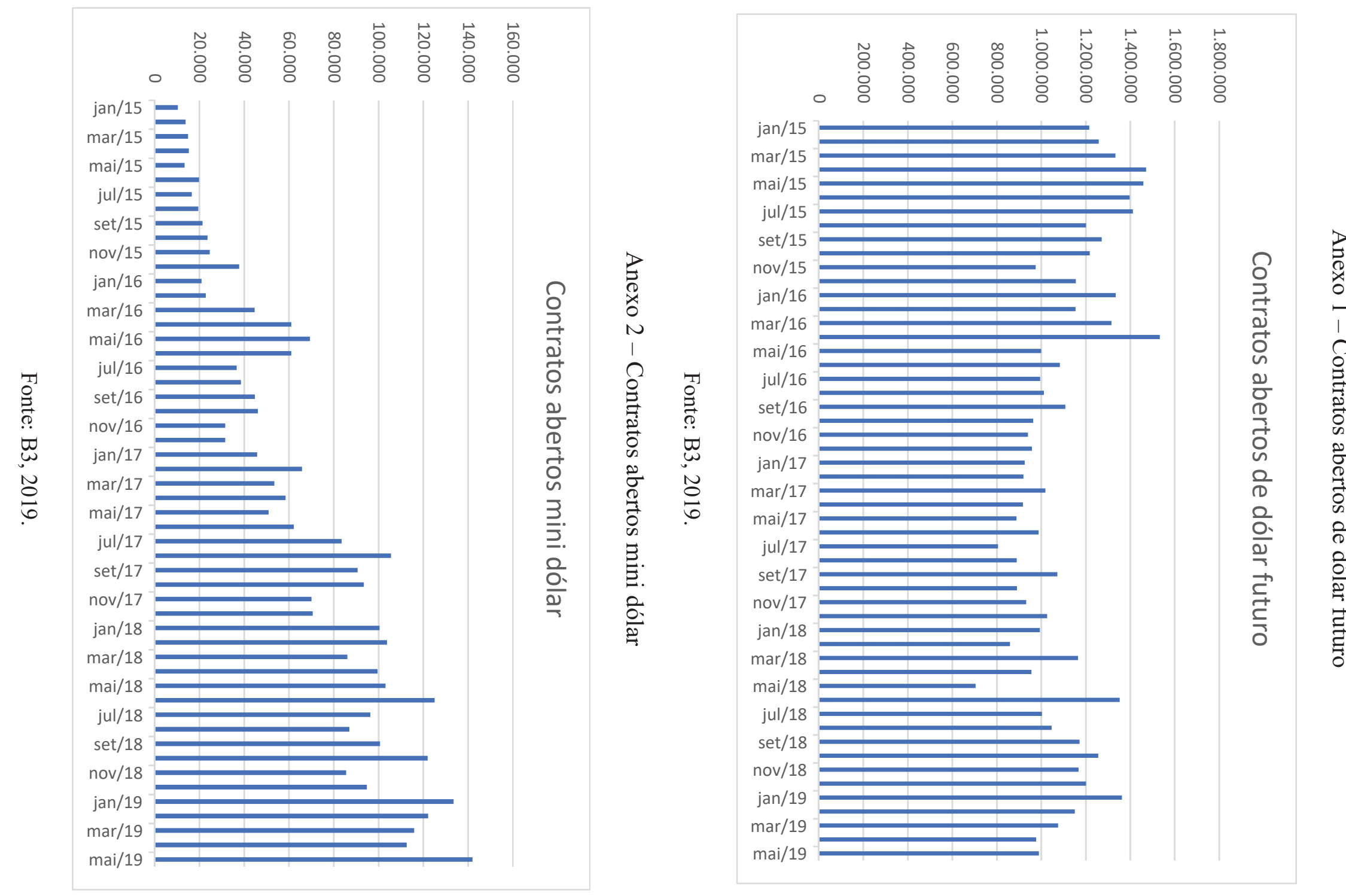
Anexo 3 - Contratos de opção de compra de dólar em aberto

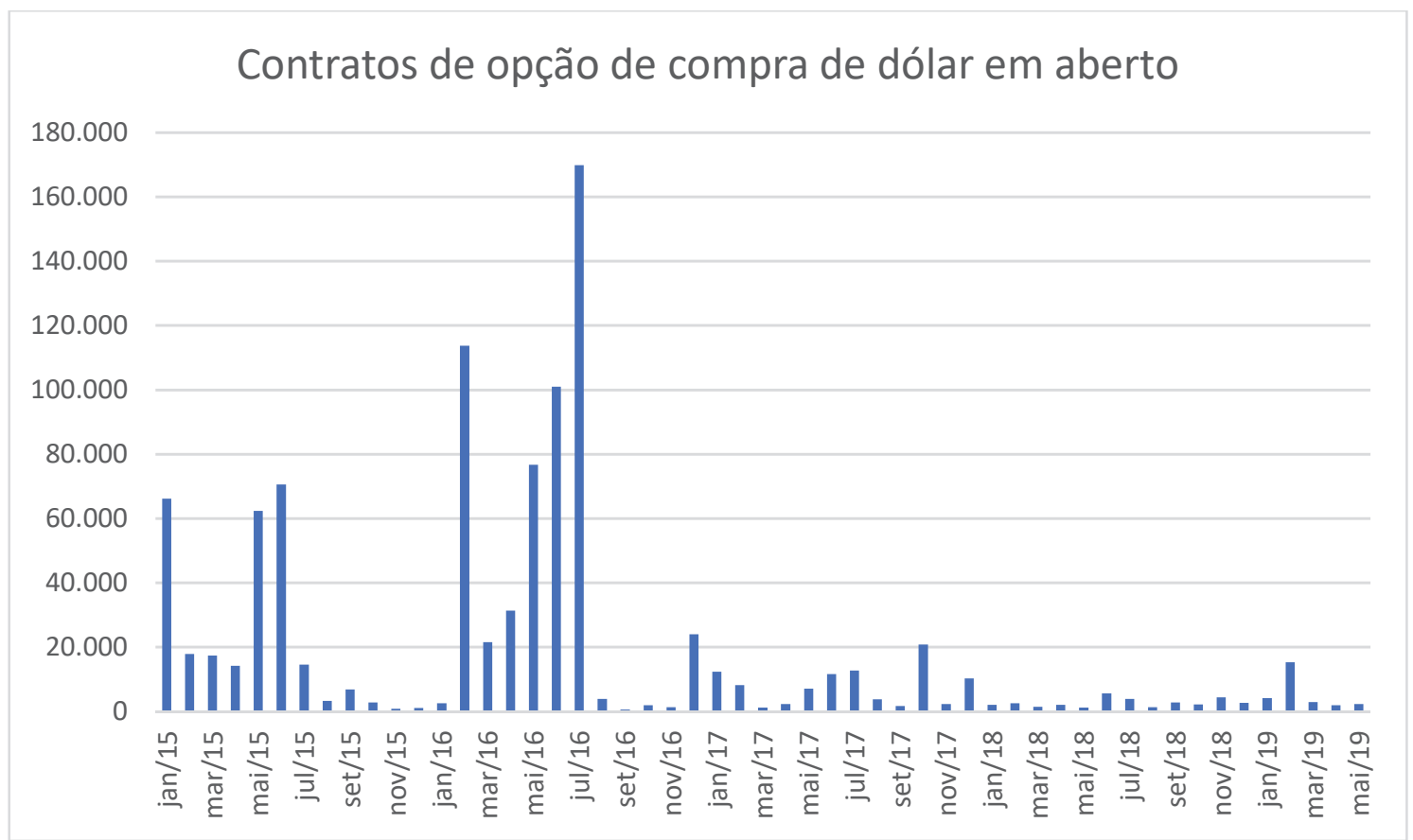

Fonte: B3, 2019.

Anexo 4 - Contratos em aberto opção de venda de dólar

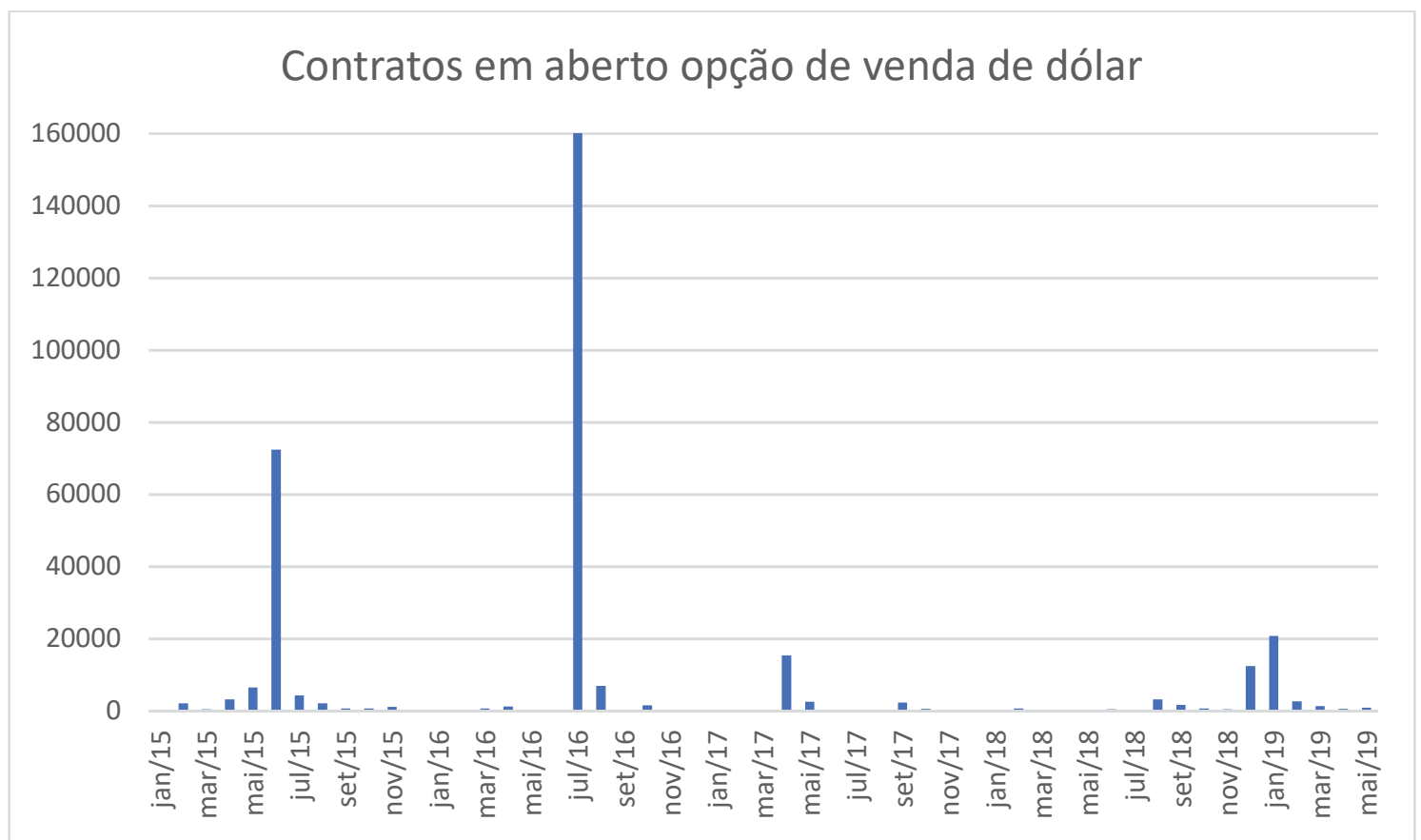

Fonte: B3, 2019. 
Anexo 5 - Tabela regressiva do imposto de renda

\begin{tabular}{|c|c|}
\hline TEMPO DE & \\
INVESTIMENTO & ALÍQUOTA \\
\hline Entre 0 e 180 dias & $22,50 \%$ \\
\hline Entre 181 e 360 dias & $20 \%$ \\
\hline Entre 361 e 720 dias & $17,50 \%$ \\
\hline Acima de 721 dias & \\
\hline
\end{tabular}

Fonte: Receita federal, 2020. 